\title{
Mechanisms Supporting the Use of Beta-Blockers for the Management of Breast Cancer Bone Metastasis
}

\author{
Maria-Bernadette Madel ${ }^{1}$ and Florent Elefteriou ${ }^{1,2, *}$ \\ 1 Department of Orthopedic Surgery, Baylor College of Medicine, Houston, TX 77030, USA; \\ Maria-Bernadette.Madel@bcm.edu \\ 2 Department of Molecular and Human Genetics, Baylor College of Medicine, Houston, TX 77030, USA \\ * Correspondence: florent.elefteriou@bcm.edu
}

check for updates

Citation: Madel, M.-B.; Elefteriou, F. Mechanisms Supporting the Use of Beta-Blockers for the Management of Breast Cancer Bone Metastasis. Cancers 2021, 13, 2887. https:// doi.org/10.3390/cancers13122887

Academic Editors: Edith Bonnelye and Patricia Ju

Received: 24 April 2021

Accepted: 8 June 2021

Published: 9 June 2021

Publisher's Note: MDPI stays neutral with regard to jurisdictional claims in published maps and institutional affiliations.

Copyright: (c) 2021 by the authors. Licensee MDPI, Basel, Switzerland. This article is an open access article distributed under the terms and conditions of the Creative Commons Attribution (CC BY) license (https:/ / creativecommons.org/licenses/by/ $4.0 /)$.
Simple Summary: Bone represents the most common site of metastasis for breast cancer and the establishment and growth of metastatic cancer cells within the skeleton significantly reduces the quality of life of patients and their survival. The interplay between sympathetic nerves and bone cells, and its influence on the process of breast cancer bone metastasis is increasingly being recognized. Several mechanisms, all dependent on $\beta$-adrenergic receptor signaling in stromal bone cells, were shown to promote the establishment of disseminated cancer cells into the skeleton. This review provides a summary of these mechanisms in support of the therapeutic potential of $\beta$-blockers for the early management of breast cancer metastasis.

Abstract: The skeleton is heavily innervated by sympathetic nerves and represents a common site for breast cancer metastases, the latter being the main cause of morbidity and mortality in breast cancer patients. Progression and recurrence of breast cancer, as well as decreased overall survival in breast cancer patients, are associated with chronic stress, a condition known to stimulate sympathetic nerve outflow. Preclinical studies have demonstrated that sympathetic stimulation of $\beta$-adrenergic receptors in osteoblasts increases bone vascular density, adhesion of metastatic cancer cells to blood vessels, and their colonization of the bone microenvironment, whereas $\beta$-blockade prevented these events in mice with high endogenous sympathetic activity. These findings in preclinical models, along with clinical data from breast cancer patients receiving $\beta$-blockers, support the pathophysiological role of excess sympathetic nervous system activity in the formation of bone metastases, and the potential of commonly used, safe, and low-cost $\beta$-blockers as adjuvant therapy to improve the prognosis of bone metastases.

Keywords: sympathetic nervous system; bone; osteoblasts; norepinephrine; adrenergic receptors; breast cancer; tumor microenvironment; metastasis

\section{Introduction}

Metastasis to distant organs represents a common and fatal complication in breast cancer patients [1,2]. About $70 \%$ of these patients experience metastatic bone disease, which can occur years after completion of the treatment of the primary tumor. Associated with a 5 -year overall survival rate of approximately $23 \%$, bone metastases represent a particularly unfavorable prognosis and can only be treated palliatively [1,3-5].

Cancer cell metastasis is a multistep process characterized by five major interrelated pathological events. As a consequence of their uncontrolled growth and low oxygen tension, tumor cells secrete proangiogenic factors that contribute to tumor vascularization. The high vascularity of the primary tumors provides a chance for metastatic cells to disseminate to other organs following detachment from the primary tumor, infiltration into the surrounding stroma, and migration through the basement membrane supporting the endothelium of local blood and/or lymphatic vessels. Intravasation into the blood/lymphatic circulation is 
followed by hematogenous or lymphagenous dissemination of a minimal number of anoikisresistant tumor cells to distant organs. In these tissues, cancer cells extravasate into the tissue stroma in response to endothelial and stroma factors to form microfoci that can remain dormant or grow into full-blown metastatic macrofoci. Those macrofoci formed in skeletal tissues will impact skeletal homeostasis, structure and endocrine function [6-10]. These steps are driven in the primary and metastatic tumor microenvironment by direct cell-to-cell and paracrine interactions between cancer cells and different stromal cells [8,11-16].

The skeleton represents a preferred organ for metastasis of breast, prostate, and lung cancers [17-22]. It is a large, richly vascularized organ, abundantly innervated by sensory nerves found in the cancellous and mainly periosteal bone compartment, as well as sympathetic nerves, mostly associated with the bone marrow vasculature, sprouting toward bone surfaces [23-32]. Recent studies in mice have shown that sensory nerves, in addition to mediating pain postnatally, play an important role in the early formation of the skeleton and in the response of the skeleton to mechanical loading and fracture $[33,34]$. In contrast, sympathetic nerves were shown to be involved in the process of bone remodeling in adult mice, under the control of hypothalamic and brainstem centers in the central nervous system, with likely relevance to age-related bone loss, a condition concurrent with the time of most skeletal metastatic occurrences.

Over the past two decades, the relevance of skeletal innervation by sympathetic nerves extended to the process of bone metastasis, starting with the observation that chronic stress was associated with enhanced recurrence rates in breast cancer patients, and with metastasis formation, reduced overall survival, and poor patient prognosis [35-44], whereas $\beta$-blocker use was associated with increased relapse-free survival [40,42,44-49]. Chronic stress stimulates activity of the hypothalamic-pituitary axis (HPA) and the sympathetic nervous system (SNS), resulting in the release of norepinephrine (NE) from sympathetic nerve terminals and the stimulation of post-synaptic $\beta$-adrenergic receptors ( $\beta$ ARs) on target cells, including bone [50] and cancer cells [51-57] (reviewed in [58]). These clinical observations were the first to support a putative role of excess sympathetic outflow in the mechanisms leading to the successful establishment of disseminated cancer cells into the skeleton. Since then, studies in vitro and in preclinical mouse models have refined our understanding of the mechanisms whereby sympathetic nerves can impact the metastatic process, and have revealed the complexity of these mechanisms. The effect of sympathetic nerves on the early stages of metastasis has recently been reviewed [58]. In the present review, we focus more specifically on mechanisms supporting the role of the SNS in the establishment of breast cancer cell metastases in the skeleton, and on how this knowledge supports the potential of $\beta$ AR blockade as a new therapeutic strategy for a better management of patients with skeletal breast cancer metastases.

\section{Sympathetic Innervation of the Skeleton and Evidence for an Interplay with the Process of Bone Metastasis}

Stress has well-defined repercussions on body homeostasis. In the short-term, it stimulates the HPA and the SNS, resulting in the release of glucocorticoids and epinephrine from the adrenal glands and of NE from sympathetic nerve terminals to support the typical fight-or-flight response and survival. Chronic stress, however, has an overall negative impact on the body and has been associated with multiple pathological conditions, including coronary heart disease [59,60], obesity [61,62], and gastrointestinal diseases [63-67]. In the context of bone health, chronic psychological stress and severe depression have been associated with higher fracture risk and low bone mineral density (BMD) [68-79]. Although this association is likely multifactorial, one of its components is thought to be the abundant innervation of the skeleton by sympathetic nerves and the action of these nerves on bone cells and bone remodeling. Sympathetic nerve fibers are indeed located in close vicinity to bone cells, including osteoblasts, osteoclasts, and bone marrow cells, which all express post-synaptic $\beta$ ARs [51-57,80-82]. Studies in mice, using isoproterenol (ISO) as a surrogate for endogenous nerve-released NE, showed that $\beta$ AR agonists cause bone loss by inhibiting osteoblast proliferation and by promoting their production of pro-osteoclastogenic factors and bone resorption $[83,84]$. On the other hand, mice lacking $\beta 2 A R$ globally or specifically 
in osteoblasts were characterized by a high bone mass, and similar outcomes were observed in mice administered with the $\beta$-blocker propranolol [83-85]. These studies thus supported the critical role of $\beta \mathrm{AR}$ signaling in bone remodeling and pointed to osteoblasts as one of the critical targets of sympathetic nerves for their action on bone homeostasis.

$\beta$-blockers are commonly used to treat cardiovascular conditions, and retrospective studies have provided additional clinical insights to support the role of sympathetic nerves in the process of bone remodeling, while confirming the clinical relevance of the aforementioned preclinical findings [86-94]. These studies also revealed that $\beta$-blocker use at time of diagnosis in patients with triple negative breast cancer (but also non-small cell lung cancer, hemangiomas, and ovarian cancer) was associated with prolonged disease-free survival and reduced metastasis development and tumor recurrence [45-49,95-102]. Since no correlation was found between the post-diagnostic use of $\beta$-blockers and breast cancer progression [103], these observations implied that the $\beta$ AR-dependent mechanisms leading to recurrence might mainly affect early stages of metastatic dissemination. As $70 \%$ of breast cancer patients succumb with skeletal metastases, these observations also suggested that sympathetic nerves, besides regulating bone homeostasis, participate in the molecular events that stimulate skeletal metastasis.

There are multiple mechanisms by which stress and sympathetic nerve activation can contribute to tumor metastasis. These include a direct effect on tumor cells, an indirect effect on the stroma of the primary tumor or distant metastatic tumor, and/or an effect on immune surveillance. Additional mechanisms might be involved, and they are not mutually exclusive. For instance, $\beta$ AR stimulation in tumor cells and surrounding stromal elements in the primary tumor, such as tumor-associated macrophages and vascular endothelial cells, promotes molecular processes involved in tumor progression. These include DNA damage repair mechanisms by activation of the ataxia-telangiectasia and Rad3-related/p21 pathway [104-106], oncogene activation including Src [107], HER2 signaling [108,109], or resistance to chemotherapy-mediated cell death [110-113]. In line with the clinical findings associating stress and enhanced recurrence rate in cancer patients [42-49], in vitro studies demonstrated that NE decreases the efficacy of chemotherapeutics [104], and pharmacological $\beta A R$ activation in breast cancer cells was shown to promote tumor cell growth and migration [114], as well as the expression of inflammatory and chemotactic cytokines required for metastasis and carcinogenesis [53,115-118]. These effects were abolished when using the $\beta$-blocker propranolol $[53,115-117]$. On the other hand, other studies showed an anti-proliferative effect of $\beta$ AR agonists [118-120]. Results regarding a direct effect of catecholamines or $\beta A R$ agonists on cancer cells are thus conflicting, but this is to be expected based on the in vitro nature of these assays, the focus on unique cell lines with specific characteristics, and the different doses of drugs used. The expression of $\alpha$ ARs and $\beta$ ARs also differs between cancer cells lines and across molecular subtype (ER, PR, and HER2 status, reviewed in [58]). $\beta 2 A R$ is the most widely expressed $\beta A R$ in basal and luminal breast cancer cell lines and in tumor samples from patients with breast cancer [58,121-123]. $\beta 2$ AR expression was found to correlate with poor prognosis of $\mathrm{ER}^{-}$breast cancer patients [123]. In another study, $\beta 2 \mathrm{AR}$ expression was associated with lower disease-free survival and higher lymph node metastasis rates in a small cohort of $\mathrm{HER}^{+}{ }^{+}$breast cancer patients [121], but opposing results were obtained in another small cohort of HER2 ${ }^{+}$patients where it was associated with improved disease-free survival [124]. Inconsistencies regarding the type or level of expression of adrenergic receptors and the effect of their agonists in breast cancer cells thus limit confidence that modulation of $\beta A R$ signaling in cancer cells may be of any solid predictive and therapeutic value, although this needs to be further examined.

$\beta 2 \mathrm{AR}$ is also widely expressed in host stromal tissues and $\beta \mathrm{AR}$ agonists can have distinct cellular targets and effects in different tissues and at specific stages of the metastatic process. The effect of $\beta A R$ agonists and antagonists on this process requires all findings to be interpreted with this in mind. Further adding complexity to the mechanisms whereby sympathetic nerves influence breast cancer tumor progression is the difference 
between pharmacological $\beta$ AR agonists and endogenous NE released by nerves in terms of adrenergic signaling and action. Pharmacological $\beta$ AR agonists indeed acutely stimulate post-synaptic receptors on cancer cells or host cells, in contrast to endogenous nervereleased NE following SNS activation via chronic stress or other means, which is buffered by homeostatic mechanisms aimed at controlling excess SNS activation. Among the multiple components of this homeostatic system, the norepinephrine transporter (NET), located in the plasma membrane of noradrenergic neurons, is responsible for NE re-uptake and recycling. It serves as the primary mechanism for inactivating noradrenergic signaling and terminating the short-term biological effects of NE in the synaptic cleft $[125,126]$, regulating adrenergic neurotransmission in the brain and peripheral organs [127,128]. NET is not only expressed in presynaptic neurons but also in bone cells, including mature osteoblasts and osteocytes $[129,130]$ and its expression decreases during aging in mice [130], pointing to a potential role of this transporter in the regulation of bone remodeling, and possibly bone metastasis, and potentially explaining conflicting results between the effect of pharmacological $\beta A R$ agonists and endogenous SNS activation on this process.

Although the assessment of an immune component is excluded in most studies related to cancer bone metastasis because of the common use of immunocompromised mice that do not reject human cancer cells, it is known that most immune cells express $\beta$ ARs and that SNS activation plays an integral role in the regulation of the anti-tumor immune response. For instance, sympathetic activation can promote the development of myeloid-derived suppressor cells (MDSCs) to favor an immunosuppressive environment [131] as well as macrophage tumor infiltration $[132,133]$. $\beta$ AR signaling stimulates the expression of TGF $\beta$, VEGF, IL-6, MMP9, and PTGS2 by macrophages, thereby promoting tumor progression and inhibiting the transcription of type I and II interferons $[132,134,135]$, which are important in cell-mediated immune responses against cancer. Furthermore, $\beta$ AR signaling can suppress the cytotoxic function of $\mathrm{T}$ cells and NK cells and contribute to the dissemination of cancer cells [136-139]. However, in vivo preclinical studies have demonstrated that stimulation of the SNS favors tumor metastasis in the absence of NK and cytotoxic T cells $[53,110,132,140,141]$, thus suggesting the existence of T- and NK-cell-independent mechanisms contributing to the engraftment of metastatic tumor cells into the skeleton.

\section{SNS-Induced Bone Stromal-Dependent Mechanisms Promote Skeletal Colonization by Cancer Cells}

Multiple observations support the notion that sympathetic nerves act on cells of the osteoblast lineage to promote the formation of skeletal metastases. An important initial suggestive evidence of such mechanisms was the observation that hematopoietic stem cells from the bone marrow environment were mobilized into the circulatory system by sympathetic nerve signals and the induction of stromal-cell-derived factor 1 (SDF1/CXCL12), a chemokine also involved in the dissemination of metastatic cells into the skeleton $[142,143]$. Osteoblasts, osteocytes, and osteoclasts predominantly express $\beta 2 \mathrm{AR}$ and can thus respond to NE released by sympathetic nerves [51,52,83,84,144-146]. Angiogenesis represents a necessary component of both invasive tumor growth and distant metastasis. One of the main inducers of angiogenesis is vascular endothelial growth factor (VEGF) [147-150], whose expression correlates with increased primary tumor microvasculature and malignancy and metastasis in breast cancer patients [151]. In vitro studies revealed that VEGF synthesis is increased upon $\beta$ AR stimulation of tumor cells [81,152] and animal studies showed that high endogenous sympathetic outflow increases VEGF and vascular density in primary tumors $[53,153,154]$. Besides its direct action on the primary tumor, the SNS also influences the vascular density of the bone marrow microenvironment. The skeleton is a highly vascularized tissue, and chondrocytes and osteoblasts are crucial regulators of angiogenesis during skeletal development and bone regeneration $[155,156]$. However, in adult mice, vascular density can be further increased upon stimulation of $\beta$ ARs in osteoblasts via $\beta 2 A R$-dependent induction of VEGF synthesis in osteoblasts [157]. This increase in VEGF and bone vascular density induced by $\beta A R$ stimulation was shown to promote breast cancer cell bone metastasis, as VEGF blockade or $\beta 2 A R$ deficiency in 
osteoblasts specifically reduced both vascularity and the number of metastatic bone lesions formed after intracardiac injection of triple negative MDA-MB-231 breast cancer cells and ISO administration [157]. Activation of $\beta$ ARs in breast cancer cell lines and osteoblasts also induces the production of IL-6, which has the potential to stimulate the $\beta$ AR-driven pro-angiogenic pathway by promoting the expression of VEGF [81,158-161] and the proliferation of breast cancer cells $[162,163]$. Therefore, a first mechanism of action whereby sympathetic nerves can promote skeletal breast cancer metastasis is through a VEGF-dependent neo-angiogenic switch upon $\beta 2 \mathrm{AR}$ signaling in osteoblasts and stimulation of bone marrow vascular density, which increases the likelihood of circulating breast cancer cells colonizing the skeleton.

The arrest of circulating cancer cells into distant organs plays a central role in the process of tumor metastasis. In this context, the adhesive interaction between tumor cells and the vascular endothelium is important. Extravasation, which brings circulating tumor cells from the blood stream into the distant tissue stroma, is initialized by attachment and rolling of tumor cells along the endothelium via selectins, such as E- and P-selectin [164-167]. This process is followed by cancer cell arrest and tight adhesion mediated by integrins, before cancer cells transmigrate through the vascular endothelium $[164,167]$. This transient interaction between cancer cells and endothelial cells is promoted by inflammatory cytokines such as IL- 1 and TNF $\alpha$, whose action is to increase the expression of adhesion proteins on the endothelium [168-172]. IL-1 $\beta$ was shown to promote the adhesion of cancer cells to endothelial cells in vitro, and administration of IL-1 $\beta$ to mice increased the number of lung and skeletal metastases, while reducing IL-1 $\beta$ activity in melanoma mouse models reduced tumor burden and metastases [173-176]. In vitro experiments demonstrated that $\beta A R$ stimulation of osteoblasts induced their expression of IL-1 $\beta$ [158]. Moreover, the conditioned medium from ISO-treated osteoblasts increased the expression of E- and Pselectin in endothelial cells and promoted the adhesion of human MDA-MB-231 breast cancer cells to these endothelial cultures, while preincubation with an IL-1 $\beta$ neutralizing antibody significantly reduced this effect [158]. Although the in vivo relevance of these data has not yet been experimentally addressed, a second level of SNS action on the bone microenvironment in the context of skeletal metastasis could thus be a stimulatory effect on osteoblast-derived IL1 $\beta$, leading to enhanced adhesive properties of the bone vascular network for metastatic cancer cells and promotion of the arrest of these cells into the skeleton, in a E/P-selectin-dependent manner.

Whether metastatic cancer cells survive and grow in their new environment after extravasation depends on multiple cell-intrinsic and stromal-derived factors. Subjecting mice to chronic immobilization stress (CIS, known to transiently activate sympathetic nerves and the HPA axis) prior to injection of cancer cells increased the efficiency of skeletal metastasis compared to non-stressed control mice [141]. These findings indicated that sympathetic activation creates a pro-metastatic microenvironment that promotes the establishment of circulating cancer cells into the skeleton. This is in line with the aforementioned proangiogenic and pro-adhesive effect of $\beta 2 \mathrm{AR}$ signaling. The administration of the $\beta$-blocker propranolol reduced this effect, confirming the contribution of endogenous sympathetic activation and $\beta A R$ signaling to this mechanism [141]. Further experiments demonstrated that the homing/migration properties of receptor activator of nuclear factor kappa-B ligand (RANKL) were involved in this context. RANKL is expressed by osteoblasts and osteocytes as well as T cells and chondrocytes [177-181], and its expression in osteoblasts and osteocytes is readily increased upon $\beta$ AR stimulation [141,145]. Besides its osteoclastogenic properties, RANKL is known to have a pro-migratory activity for RANK-expressing cancer cells $[84,114,182-185]$. High RANK expression (the receptor for RANKL) in the tumors of breast cancer patients was associated with poor prognosis and the combined expression of RANK and CXCR4 in breast cancer patients predicted recurrence of bone metastases [186,187]. In vitro, the observation that the conditioned medium of ISO-treated osteoblasts stimulated the migration of breast cancer cells, and that the RANKL decoy receptor osteoprotegerin (OPG) could block it, supported a stimulatory effect of $\beta$ AR activa- 
tion on breast cancer cell migration, via the upregulation of RANKL expression by the host stromal compartment [141]. These results were reinforced by the reduction in MDA-MD231 cancer cell migration in vitro and bone metastasis in vivo following $\beta$ AR stimulation and knockdown of RANK in breast cancer cells [141]. In conclusion and collectively, these results suggest that stimulation of $\beta A R$ signaling in osteoblasts following activation of sympathetic nerves favors the colonization of the bone marrow environment by circulating breast cancer cells at multiple steps of the metastatic process, via (a) the promotion of a VEGF-dependent neoangiogenic switch leading to higher bone vascular density and (b) an IL-1 $\beta$-dependent increase in the adhesive properties of this newly created vasculature, both of which potentially increase the likelihood of circulating breast cancer cells to arrest in bone tissues, and (c) a RANKL-dependent increase in cancer cell homing or retention into bone tissues, due to higher migratory activity toward RANKL-secreting niches (Figure 1). It is worth noting that osteocytes represent an essential source of RANKL during bone remodeling [5,188], and that $\beta$-adrenergic signals not only promote RANKL expression in osteoblasts but also in osteocytes [145]. Whether osteoblasts or osteocytes, or both, are targets of sympathetic-nerve-derived NE for its action on bone metastasis remains unknown.

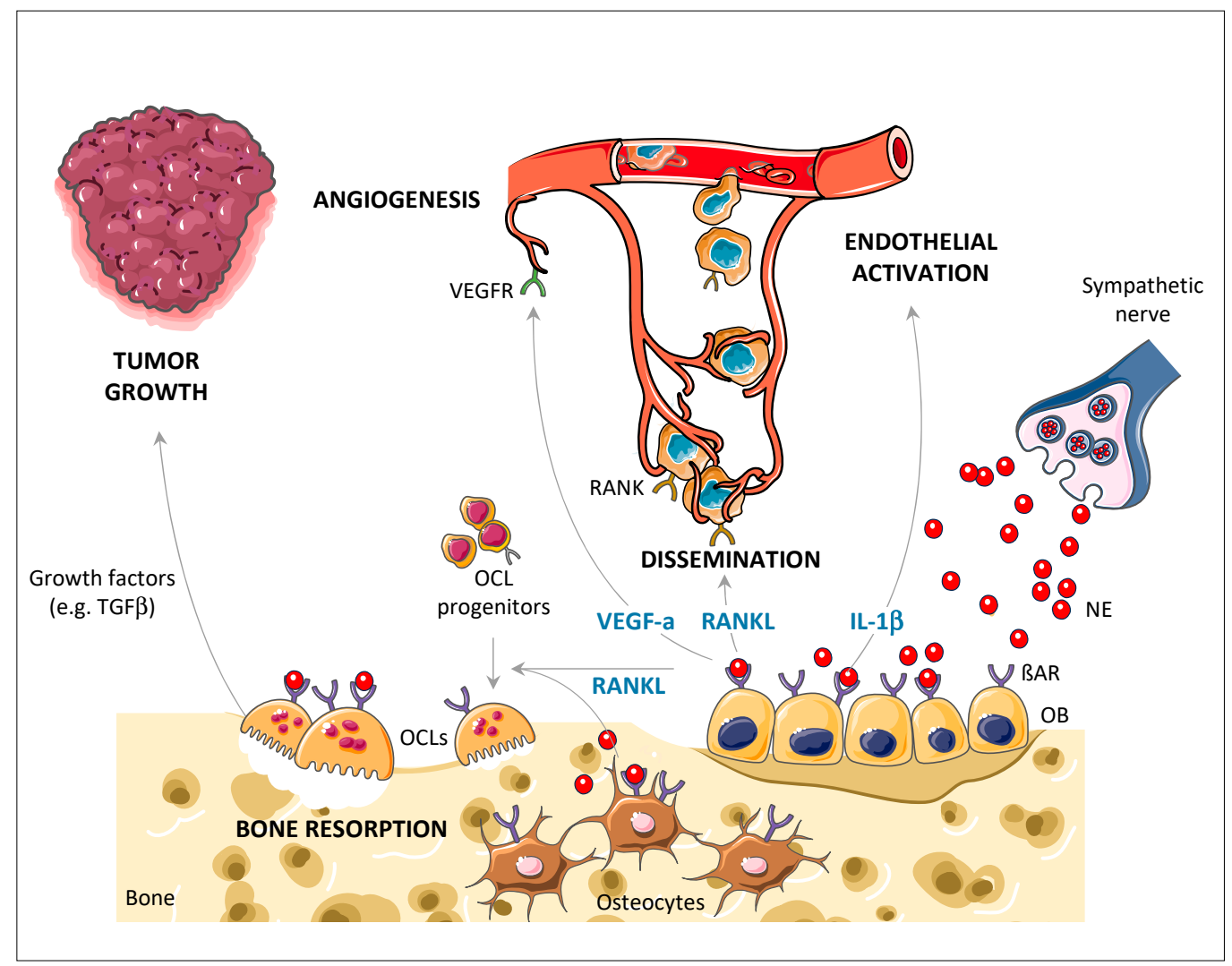

Figure 1. Overview of the different mechanisms by which sympathetic nerve activation promotes the establishment of metastatic breast cancer cells in the skeleton. Secretion of NE from sympathetic nerve terminals in the bone microenvironment stimulates post-synaptic $\beta$ ARs on various target cells, including bone and cancer cells. $\beta$ AR activation on osteoblasts results in increased IL-1 $\beta$, VEGF-a, and RANKL secretion, leading to endothelial activation and neoangiogenesis as well as tumor stromal retention and increased osteoclastogenesis, respectively. It also promotes tumor growth through increased osteoclastogenesis, bone resorption, and subsequent release of bone-derived growth factors such as TGF $\beta$. $\beta$ AR, $\beta$-adrenergic receptor; OB, osteoblast; OCL, osteoclast; NE, norepinephrine; RANK, receptor activator of nuclear factor kappa-B; RANKL, receptor activator of nuclear factor kappa-B ligand; VEGF-a, vascular endothelial growth factor A; VEGFR, vascular endothelial growth factor receptor. 
Although pro-angiogenic and cancer cell bone-homing properties of $\beta$ AR stimulation in the osteoblast lineage are mainly relevant to the early establishment of circulating breast cancer cells in the bone marrow environment, RANKL and IL-6 are, before all, two wellknown potent osteoclastogenic cytokines [158,189-191]. Their high expression following $\beta A R 2$ stimulation is likely to contribute to the development of osteolytic lesions and tumor progression through enhanced osteoclastogenesis once tumor cells are established in the skeleton $[83,192]$. Direct $\beta A R$-mediated stimulation of osteoclast differentiation has also been observed [193] and was reported to enhance the bone resorbing activity of $\beta$ AR-expressing osteoclasts in vitro [194]. In addition, bone-derived growth factors, such as TGF $\beta$, are released from the bone matrix during osteoclast-mediated resorption to promote the proliferation and survival of tumor cells [195-202]. Evidence that TGF $\beta$ plays a decisive role in tumor growth was substantiated by the demonstration that bone metastases can be effectively reduced by the TGF $\beta$ signaling blockade [200,202-207]. Therefore, stimulation of $\beta A R$ in the osteoblast lineage and its effect on osteoclasts may not only favor the establishment of bone metastases at early disease stage but also fuel the feed-forward cycle of bone destruction at later stages of the bone metastatic process, by promoting osteoclastogenesis and the release of growth factors from the bone matrix [208]. The more recent discovery of the deleterious impact of bone-metastasis-derived TGF $\beta$ on the muscular system [209-211] also implies that high sympathetic nervous system activity would be associated with muscle weakness in the context of skeletal metastasis. In addition to their bone resorption function, osteoclasts are, as their progenitors, antigen-presenting cells [212]. Depending on their origin and environment, these cells induce regulatory $\mathrm{CD}^{+}$and $\mathrm{CD}^{+} \mathrm{T}$ cells [213-215] or inflammatory $\mathrm{TNF} \alpha$-producing $\mathrm{CD}^{+} \mathrm{T}$ cells [213]. Recently, an immunosuppressive subset of $\mathrm{Cx} 3 \mathrm{cr} 1^{+}$osteoclasts was identified as promoting a pro-metastatic bone marrow microenvironment through its strong immunosuppressive capacity and upregulation of immunosuppressive checkpoint molecules including programmed death ligand 1 (PD-1L), herpes virus entry mediator (HVEM), and galectin 9 [216]. The immunosuppressive capacity of osteoclasts has also been described in the context of multiple myeloma, where the production of immunosuppressive molecules such as indoleamine 2,3-dioxygenase (IDO) and PD-L1 by osteoclasts protects myeloma cells against T-cell-mediated cytotoxicity [217]. Whether direct $\beta A R$ activation in osteoclasts affects their immune function and whether this could entail an immunosuppressive and pro-metastatic microenvironment in the bone marrow remains to be investigated. Lastly, osteoclasts were shown to secrete miRNAs that trigger cancer cell proliferation, tumor cell survival, and angiogenesis [218-220]. Whether stimulation of adrenergic signals enhances this release and thus promotes a pro-tumorigenic microenvironment has yet to be addressed.

\section{Treatment Strategies to Limit Metastatic Cancer Cell Engraftment into the Skeleton}

Despite the successful use of anti-resorptive molecules such as bisphosphonates to limit bone pain and fracture as standard-of-care for patients with established bone metastases [221-223], the development of drug resistance and the persistence of minimal residual disease hampers cancer remission. An important implication of the findings summarized above is that $\beta A R$ blockade should reduce the levels of VEGF, IL-1 $\beta$, and RANKL produced by osteoblasts (and presumably osteocytes) in response to sympathetic activation, and thus offer some level of protection against bone metastatic events. It is important to emphasize that, in addition to a number of social stressors, the diagnosis of cancer and its treatment have a significant impact on the stress level of patients [44,224-228]. $\beta$-blockers are used for the treatment of multiple conditions, including congestive heart failure, hypertension, migraines, infantile hemangioma, and thyrotoxicosis [229]. The safety profile of these drugs is well-described, it is not associated with an increased incidence of breast cancer $[230,231]$, and several clinical and preclinical studies support their use as adjuvant therapy in the treatment of breast cancer [45-49,95-102,232-234]. This beneficial effect of $\beta$-blockers on breast cancer patient survival, reduction of tumor recurrence, and reduced 
incidence of metastasis (summarized by Conceição and colleges [58]), remains, however, controversial because most of these studies present limitations, including retrospective design, small population size, difficulty in assessing duration of $\beta$-blocker treatment, or lack of data about comorbidities and intake of other medications. Nevertheless, improved relapse-free survival [45] and reduced metastasis and tumor recurrence were observed in breast cancer patients receiving $\beta$-blockers $[46,48]$, and consistent with what was observed in some preclinical studies [141], a positive correlation was observed in patients taking propranolol the year before breast cancer diagnosis, specifically regarding tumor invasion and metastatic involvement at diagnosis, as well as reduced cancer-specific mortality [47]. This observation and the fact that there was no association between post-diagnostic use of $\beta$-blockers and breast cancer-specific mortality and progression [103] support the notion that metastatic dissemination, and not metastatic tumor growth, is the most relevant target of sympathetic nerves and that $\beta$-blocker therapy could improve prognosis. Of note, synergy was detected between $\beta$-blockers and chemotherapy in mice in terms of anti-tumor effect at the primary site and improved survival [235], thus further supporting the use of $\beta$-blockers concurrently with chemotherapy in the management of breast cancer. Although blockade of $\beta$ AR signaling represents an attractive strategy to complement current therapeutic options, preclinical and adequately powered clinical trials focusing on overall survival and cancer recurrence are still needed to assess the therapeutic potential of $\beta$-blockers to restrain breast cancer bone metastasis. Whether the protective effect of non-selective $\beta$-blockers on skeletal metastasis is mediated by action on $\beta 1 \mathrm{AR}$ or $\beta 2 \mathrm{AR}$ also remains uncertain. It should be noted that $\beta 1 \mathrm{AR}$ blockade but not non-selective $\beta$ AR blockade reduced bone resorption and had a favorable effect on cancellous BMD in clinical studies [94]. This action of $\beta$-blockers on BMD is another incentive to further evaluate this class of drugs for the treatment of cancer patients at risk of bone loss and fracture, especially since there are concerns regarding rare side-effects of current treatments targeting osteoclasts, such as osteonecrosis of the jaw or atypical femoral fractures [236]. One should also be aware of a recent study showing that the effect of $\beta$-blockers on overall survival may vary depending on the different subtypes of breast cancer-in contrast to improved relapse-free survival in patients with triple negative breast cancer $[45,48,233,237]$, the pre-existing use of $\beta$-blockers in patients with advanced-stage HER2-positive breast cancer prior to anti-HER2 therapy initiation was associated with reduced overall survival compared to patients without $\beta$-blocker intake [238].

\section{Conclusions}

Preclinical studies in mice demonstrated that stimulation of $\beta 2 A R$ in osteoblasts promotes bone vascular density and the colonization of the bone microenvironment by metastatic breast cancer cells, and that pharmacological inhibition of $\beta$ AR signaling by $\beta$-blockers inhibits skeletal colonization by metastatic cancer cells. These observations support the contribution of sympathetic nerves to the process of breast cancer bone metastasis, but there are still many unanswered questions to fully understand how these nerves change the behavior of metastatic cancer cells and the properties of their stroma along the multiple steps of the metastatic process. Variables in this equation include the variety of adrenergic receptors expressed by tumor cells and stromal cells, differential signaling upon various ligands, and the multiple homeostatic mechanisms regulating endogenous sympathetic NE release and AR signaling in both presynaptic and post-synaptic cells, as well as the contribution of various immune cells. Much remains to be done to broaden findings in different animal models of bone metastasis, in immunocompetent animals, and with different types of cancer cells. Clinical studies are also still needed to confirm the beneficial effect of low cost, safe $\beta$-blockers on cancer cell bone metastasis and relapse-free survival.

Author Contributions: Conceptualization, writing, review and editing, M.-B.M. and F.E. All authors have read and agreed to the published version of the manuscript. 
Funding: This research was funded by NCI R01 CA168717 and NIH R01 AG055394.

Institutional Review Board Statement: Not applicable.

Informed Consent Statement: Not applicable.

Data Availability Statement: No new data were created or analyzed in this study. Data sharing is not applicable to this article.

Conflicts of Interest: The authors declare no conflict of interest.

\section{References}

1. Manders, K.; van de Poll-Franse, L.V.; Creemers, G.-J.; Vreugdenhil, G.; van der Sangen, M.J.; Nieuwenhuijzen, G.A.; Roumen, R.M.; Voogd, A.C. Clinical management of women with metastatic breast cancer: A descriptive study according to age group. BMC Cancer 2006, 6, 179. [CrossRef] [PubMed]

2. Coleman, R.E. Clinical features of metastatic bone disease and risk of skeletal morbidity. Clin. Cancer Res. 2006, 12, 6243s-6249s. [CrossRef] [PubMed]

3. Kennecke, H.; Yerushalmi, R.; Woods, R.; Cheang, M.C.U.; Voduc, D.; Speers, C.H.; Nielsen, T.O.; Gelmon, K. Metastatic Behavior of Breast Cancer Subtypes. J. Clin. Oncol. 2010, 28, 3271-3277. [CrossRef]

4. Coleman, R.; Smith, P.; Rubens, R. Clinical course and prognostic factors following bone recurrence from breast cancer. Br. J. Cancer 1998, 77, 336-340. [CrossRef]

5. Xiong, J.; Onal, M.; Jilka, R.L.; Weinstein, R.S.; Manolagas, S.C.; O’Brien, C.A. Matrix-embedded cells control osteoclast formation. Nat. Med. 2011, 17, 1235-1241. [CrossRef]

6. Käkönen, S.-M.; Mundy, G.R. Mechanisms of osteolytic bone metastases in breast carcinoma. Cancer 2003, 97, 834-839. [CrossRef] [PubMed]

7. van Zijl, F.; Krupitza, G.; Mikulits, W. Initial steps of metastasis: Cell invasion and endothelial transmigration. Mutat. Res. 2011, 728, 23-34. [CrossRef]

8. Nguyen, D.X.; Bos, P.D.; Massagué, J. Metastasis: From dissemination to organ-specific colonization. Nat. Rev. Cancer 2009, 9, 274-284. [CrossRef]

9. Feller, L.; Kramer, B.; Lemmer, J. Pathobiology of cancer metastasis: A short account. Cancer Cell Int. 2012, 12, 24. [CrossRef]

10. Alizadeh, A.M.; Shiri, S.; Farsinejad, S. Metastasis review: From bench to bedside. Tumour Biol. 2014, 35, 8483-8523. [CrossRef]

11. Nguyen, D.X.; Massagué, J. Genetic determinants of cancer metastasis. Nat. Rev. Genet. 2007, 8, 341-352. [CrossRef]

12. Wels, J.; Kaplan, R.N.; Rafii, S.; Lyden, D. Migratory neighbors and distant invaders: Tumor-associated niche cells. Genes Dev. 2008, 22, 559-574. [CrossRef]

13. Chiang, A.C.; Massagué, J. Molecular basis of metastasis. N. Engl. J. Med. 2008, 359, 2814-2823. [CrossRef]

14. Sikes, R.A.; Nicholson, B.E.; Koeneman, K.S.; Edlund, N.M.; Bissonette, E.A.; Bradley, M.J.; Thalmann, G.N.; Cecchini, M.G.; Pienta, K.J.; Chung, L.W.K. Cellular interactions in the tropism of prostate cancer to bone. Int. J. Cancer 2004, 110, 497-503. [CrossRef]

15. Kang, Y.; Siegel, P.M.; Shu, W.; Drobnjak, M.; Kakonen, S.M.; Cordón-Cardo, C.; Guise, T.A.; Massagué, J. A multigenic program mediating breast cancer metastasis to bone. Cancer Cell 2003, 3, 537-549. [CrossRef]

16. Minn, A.J.; Kang, Y.; Serganova, I.; Gupta, G.P.; Giri, D.D.; Doubrovin, M.; Ponomarev, V.; Gerald, W.L.; Blasberg, R.; Massagué, J. Distinct organ-specific metastatic potential of individual breast cancer cells and primary tumors. J. Clin. Investig. 2005, 115, 44-55. [CrossRef]

17. Hill, E.L.; Elde, R. Distribution of CGRP-, VIP-, D beta H-, SP-, and NPY-immunoreactive nerves in the periosteum of the rat. Cell Tissue Res. 1991, 264, 469-480. [CrossRef] [PubMed]

18. Elefteriou, F. Role of sympathetic nerves in the establishment of metastatic breast cancer cells in bone. J. Bone Oncol. 2016, 5, 132-134. [CrossRef] [PubMed]

19. Patel, M.S.; Elefteriou, F. The new field of neuroskeletal biology. Calcif. Tissue Int. 2007, 80, 337-347. [CrossRef]

20. Artico, M.; Bosco, S.; Cavallotti, C.; Agostinelli, E.; Giuliani-Piccari, G.; Sciorio, S.; Cocco, L.; Vitale, M. Noradrenergic and cholinergic innervation of the bone marrow. Int. J. Mol. Med. 2002, 10, 77-80. [CrossRef] [PubMed]

21. Mach, D.B.; Rogers, S.D.; Sabino, M.C.; Luger, N.M.; Schwei, M.J.; Pomonis, J.D.; Keyser, C.P.; Clohisy, D.R.; Adams, D.J.; O’Leary, P.; et al. Origins of skeletal pain: Sensory and sympathetic innervation of the mouse femur. Neuroscience 2002, 113, 155-166. [CrossRef]

22. Goblirsch, M.J.; Zwolak, P.P.; Clohisy, D.R. Biology of bone cancer pain. Clin. Cancer Res. 2006, 12, 6231s-6235s. [CrossRef] [PubMed]

23. Lorenz, M.R.; Brazill, J.M.; Beeve, A.T.; Shen, I.; Scheller, E.L. A neuroskeletal atlas: Spatial mapping and contextualization of axon subtypes innervating the long bones of $\mathrm{C} 3 \mathrm{H}$ and $\mathrm{B} 6$ mice. J. Bone Miner. Res. 2021. [CrossRef] [PubMed]

24. Sayilekshmy, M.; Hansen, R.B.; Delaissé, J.-M.; Rolighed, L.; Andersen, T.L.; Heegaard, A.-M. Innervation is higher above Bone Remodeling Surfaces and in Cortical Pores in Human Bone: Lessons from patients with primary hyperparathyroidism. Sci. Rep. 2019, 9, 5361. [CrossRef] [PubMed] 
25. Ahmed, M.; Bjurholm, A.; Kreicbergs, A.; Schultzberg, M. Neuropeptide Y, tyrosine hydroxylase and vasoactive intestinal polypeptide-immunoreactive nerve fibers in the vertebral bodies, discs, dura mater, and spinal ligaments of the rat lumbar spine. Spine 1993, 18, 268-273. [CrossRef] [PubMed]

26. Fan, W.; Bouwense, S.A.W.; Crawford, R.; Xiao, Y. Structural and cellular features in metaphyseal and diaphyseal periosteum of osteoporotic rats. J. Mol. Histol. 2010, 41, 51-60. [CrossRef] [PubMed]

27. Hukkanen, M.; Konttinen, Y.T.; Rees, R.G.; Santavirta, S.; Terenghi, G.; Polak, J.M. Distribution of nerve endings and sensory neuropeptides in rat synovium, meniscus and bone. Int. J. Tissue React. 1992, 14, 1-10.

28. Imai, S.; Tokunaga, Y.; Maeda, T.; Kikkawa, M.; Hukuda, S. Calcitonin gene-related peptide, substance P, and tyrosine hydroxylaseimmunoreactive innervation of rat bone marrows: An immunohistochemical and ultrastructural investigation on possible efferent and afferent mechanisms. J. Orthop. Res. 1997, 15, 133-140. [CrossRef]

29. Chartier, S.R.; Mitchell, S.A.T.; Majuta, L.A.; Mantyh, P.W. The Changing Sensory and Sympathetic Innervation of the Young, Adult and Aging Mouse Femur. Neuroscience 2018, 387, 178-190. [CrossRef]

30. Castañeda-Corral, G.; Jimenez-Andrade, J.M.; Bloom, A.P.; Taylor, R.N.; Mantyh, W.G.; Kaczmarska, M.J.; Ghilardi, J.R.; Mantyh, P.W. The majority of myelinated and unmyelinated sensory nerve fibers that innervate bone express the tropomyosin receptor kinase A. Neuroscience 2011, 178, 196-207. [CrossRef]

31. Martin, C.D.; Jimenez-Andrade, J.M.; Ghilardi, J.R.; Mantyh, P.W. Organization of a unique net-like meshwork of CGRP+ sensory fibers in the mouse periosteum: Implications for the generation and maintenance of bone fracture pain. Neurosci. Lett. 2007, 427, 148-152. [CrossRef]

32. Jimenez-Andrade, J.M.; Mantyh, W.G.; Bloom, A.P.; Xu, H.; Ferng, A.S.; Dussor, G.; Vanderah, T.W.; Mantyh, P.W. A phenotypically restricted set of primary afferent nerve fibers innervate the bone versus skin: Therapeutic opportunity for treating skeletal pain. Bone 2010, 46, 306-313. [CrossRef] [PubMed]

33. Tomlinson, R.E.; Li, Z.; Zhang, Q.; Goh, B.C.; Li, Z.; Thorek, D.L.J.; Rajbhandari, L.; Brushart, T.M.; Minichiello, L.; Zhou, F.; et al. NGF-TrkA Signaling by Sensory Nerves Coordinates the Vascularization and Ossification of Developing Endochondral Bone. Cell Rep. 2016, 16, 2723-2735. [CrossRef] [PubMed]

34. Tomlinson, R.E.; Li, Z.; Li, Z.; Minichiello, L.; Riddle, R.C.; Venkatesan, A.; Clemens, T.L. NGF-TrkA signaling in sensory nerves is required for skeletal adaptation to mechanical loads in mice. Proc. Natl. Acad. Sci. USA 2017, 114, E3632-E3641. [CrossRef]

35. Moreno-Smith, M.; Lutgendorf, S.K.; Sood, A.K. Impact of stress on cancer metastasis. Future Oncol. 2010, 6, 1863-1881. [CrossRef] [PubMed]

36. Heffner, K.L.; Loving, T.J.; Robles, T.F.; Kiecolt-Glaser, J.K. Examining psychosocial factors related to cancer incidence and progression: In search of the silver lining. Brain. Behav. Immun. 2003, 17 (Suppl. 1), S109-S111. [CrossRef]

37. Clouston, S.A.P.; Kuan, P.; Kotov, R.; Mukherjee, S.; Thompson-Carino, P.; Bromet, E.J.; Luft, B.J. Risk factors for incident prostate cancer in a cohort of world trade center responders. BMC Psychiatry 2019, 19, 389. [CrossRef]

38. Kikuchi, N.; Nishiyama, T.; Sawada, T.; Wang, C.; Lin, Y.; Watanabe, Y.; Tamakoshi, A.; Kikuchi, S. Perceived Stress and Colorectal Cancer Incidence: The Japan Collaborative Cohort Study. Sci. Rep. 2017, 7, 40363. [CrossRef]

39. Vahdaninia, M.; Omidvari, S.; Montazeri, A. What do predict anxiety and depression in breast cancer patients? A follow-up study. Soc. Psychiatry Psychiatr. Epidemiol. 2010, 45, 355-361. [CrossRef]

40. Giese-Davis, J.; Wilhelm, F.H.; Conrad, A.; Abercrombie, H.C.; Sephton, S.; Yutsis, M.; Neri, E.; Taylor, C.B.; Kraemer, H.C.; Spiegel, D. Depression and stress reactivity in metastatic breast cancer. Psychosom. Med. 2006, 68, 675-683. [CrossRef]

41. Ross, K. Mapping pathways from stress to cancer progression. J. Natl. Cancer Inst. 2008, 100, 914-915. [CrossRef]

42. Burgess, C.; Cornelius, V.; Love, S.; Graham, J.; Richards, M.; Ramirez, A. Depression and anxiety in women with early breast cancer: Five year observational cohort study. BMJ 2005, 330, 702. [CrossRef] [PubMed]

43. Spiegel, D.; Giese-Davis, J. Depression and cancer: Mechanisms and disease progression. Biol. Psychiatry 2003, 54, 269-282. [CrossRef]

44. Chida, Y.; Hamer, M.; Wardle, J.; Steptoe, A. Do stress-related psychosocial factors contribute to cancer incidence and survival? Nat. Clin. Pract. Oncol. 2008, 5, 466-475. [CrossRef]

45. Melhem-Bertrandt, A.; Chavez-Macgregor, M.; Lei, X.; Brown, E.N.; Lee, R.T.; Meric-Bernstam, F.; Sood, A.K.; Conzen, S.D.; Hortobagyi, G.N.; Gonzalez-Angulo, A.-M. Beta-blocker use is associated with improved relapse-free survival in patients with triple-negative breast cancer. J. Clin. Oncol. 2011, 29, 2645-2652. [CrossRef] [PubMed]

46. Powe, D.G.; Voss, M.J.; Zänker, K.S.; Habashy, H.O.; Green, A.R.; Ellis, I.O.; Entschladen, F. Beta-blocker drug therapy reduces secondary cancer formation in breast cancer and improves cancer specific survival. Oncotarget 2010, 1, 628-638. [CrossRef]

47. Barron, T.I.; Connolly, R.M.; Sharp, L.; Bennett, K.; Visvanathan, K. Beta blockers and breast cancer mortality: A populationbased study. J. Clin. Oncol. 2011, 29, 2635-2644. [CrossRef] [PubMed]

48. Botteri, E.; Munzone, E.; Rotmensz, N.; Cipolla, C.; De Giorgi, V.; Santillo, B.; Zanelotti, A.; Adamoli, L.; Colleoni, M.; Viale, G.; et al. Therapeutic effect of $\beta$-blockers in triple-negative breast cancer postmenopausal women. Breast Cancer Res. Treat. 2013, 140, 567-575. [CrossRef]

49. Choi, C.H.; Song, T.; Kim, T.H.; Choi, J.K.; Park, J.-Y.; Yoon, A.; Lee, Y.-Y.; Kim, T.-J.; Bae, D.-S.; Lee, J.-W.; et al. Meta-analysis of the effects of beta blocker on survival time in cancer patients. J. Cancer Res. Clin. Oncol. 2014, 140, 1179-1188. [CrossRef]

50. Elefteriou, F. Impact of the Autonomic Nervous System on the Skeleton. Physiol. Rev. 2018, 98, 1083-1112. [CrossRef] 
51. Ma, Y.; Nyman, J.S.; Tao, H.; Moss, H.H.; Yang, X.; Elefteriou, F. $\beta 2$-Adrenergic receptor signaling in osteoblasts contributes to the catabolic effect of glucocorticoids on bone. Endocrinology 2011, 152, 1412-1422. [CrossRef] [PubMed]

52. Elefteriou, F.; Campbell, P.; Ma, Y. Control of bone remodeling by the peripheral sympathetic nervous system. Calcif. Tissue Int. 2014, 94, 140-151. [CrossRef]

53. Thaker, P.H.; Han, L.Y.; Kamat, A.A.; Arevalo, J.M.; Takahashi, R.; Lu, C.; Jennings, N.B.; Armaiz-Pena, G.; Bankson, J.A.; Ravoori, M.; et al. Chronic stress promotes tumor growth and angiogenesis in a mouse model of ovarian carcinoma. Nat. Med. 2006, 12, 939-944. [CrossRef]

54. Shimizu, N.; Hori, T.; Nakane, H. An interleukin-1 beta-induced noradrenaline release in the spleen is mediated by brain corticotropin-releasing factor: An in vivo microdialysis study in conscious rats. Brain Behav. Immun. 1994, 8, 14-23. [CrossRef]

55. Madden, K.S.; Sanders, V.M.; Felten, D.L. Catecholamine influences and sympathetic neural modulation of immune responsiveness. Annu. Rev. Pharmacol. Toxicol. 1995, 35, 417-448. [CrossRef]

56. Badino, G.R.; Novelli, A.; Girardi, C.; Di Carlo, F. Evidence for functional beta-adrenoceptor subtypes in CG-5 breast cancer cell. Pharmacol. Res. 1996, 33, 255-260. [CrossRef] [PubMed]

57. Schuller, H.M.; Cole, B. Regulation of cell proliferation by beta-adrenergic receptors in a human lung adenocarcinoma cell line. Carcinogenesis 1989, 10, 1753-1755. [CrossRef]

58. Conceição, F.; Sousa, D.M.; Paredes, J.; Lamghari, M. Sympathetic activity in breast cancer and metastasis: Partners in crime. Bone Res. 2021, 9, 9. [CrossRef] [PubMed]

59. Kubzansky, L.D.; Koenen, K.C.; Spiro, A.; Vokonas, P.S.; Sparrow, D. Prospective study of posttraumatic stress disorder symptoms and coronary heart disease in the Normative Aging Study. Arch. Gen. Psychiatry 2007, 64, 109-116. [CrossRef]

60. Cohen, B.E.; Marmar, C.R.; Neylan, T.C.; Schiller, N.B.; Ali, S.; Whooley, M.A. Posttraumatic stress disorder and health-related quality of life in patients with coronary heart disease: Findings from the Heart and Soul Study. Arch. Gen. Psychiatry 2009, 66, 1214-1220. [CrossRef] [PubMed]

61. Block, J.P.; He, Y.; Zaslavsky, A.M.; Ding, L.; Ayanian, J.Z. Psychosocial stress and change in weight among US adults. Am. J. Epidemiol. 2009, 170, 181-192. [CrossRef]

62. Gluck, M.E.; Geliebter, A.; Hung, J.; Yahav, E. Cortisol, hunger, and desire to binge eat following a cold stress test in obese women with binge eating disorder. Psychosom. Med. 2004, 66, 876-881. [CrossRef] [PubMed]

63. Jansson, C.; Wallander, M.-A.; Johansson, S.; Johnsen, R.; Hveem, K. Stressful psychosocial factors and symptoms of gastroesophageal reflux disease: A population-based study in Norway. Scand. J. Gastroenterol. 2010, 45, 21-29. [CrossRef] [PubMed]

64. Fass, R.; Naliboff, B.D.; Fass, S.S.; Peleg, N.; Wendel, C.; Malagon, I.B.; Mayer, E.A. The effect of auditory stress on perception of intraesophageal acid in patients with gastroesophageal reflux disease. Gastroenterology 2008, 134, 696-705. [CrossRef] [PubMed]

65. Levenstein, S.; Prantera, C.; Varvo, V.; Scribano, M.L.; Andreoli, A.; Luzi, C.; Arcà, M.; Berto, E.; Milite, G.; Marcheggiano, A. Stress and exacerbation in ulcerative colitis: A prospective study of patients enrolled in remission. Am. J. Gastroenterol. 2000, 95, 1213-1220. [CrossRef]

66. Mittermaier, C.; Dejaco, C.; Waldhoer, T.; Oefferlbauer-Ernst, A.; Miehsler, W.; Beier, M.; Tillinger, W.; Gangl, A.; Moser, G. Impact of depressive mood on relapse in patients with inflammatory bowel disease: A prospective 18-month follow-up study. Psychosom. Med. 2004, 66, 79-84. [CrossRef]

67. Maunder, R.G.; Greenberg, G.R.; Hunter, J.J.; Lancee, W.J.; Steinhart, A.H.; Silverberg, M.S. Psychobiological subtypes of ulcerative colitis: pANCA status moderates the relationship between disease activity and psychological distress. Am. J. Gastroenterol. 2006, 101, 2546-2551. [CrossRef] [PubMed]

68. Erez, H.B.; Weller, A.; Vaisman, N.; Kreitler, S. The relationship of depression, anxiety and stress with low bone mineral density in post-menopausal women. Arch. Osteoporos. 2012, 7, 247-255. [CrossRef] [PubMed]

69. Cizza, G.; Primma, S.; Coyle, M.; Gourgiotis, L.; Csako, G. Depression and osteoporosis: A research synthesis with meta-analysis. Horm. Metab. Res. 2010, 42, 467-482. [CrossRef]

70. Huang, W.-S.; Hsu, J.-W.; Huang, K.-L.; Bai, Y.-M.; Su, T.-P.; Li, C.-T.; Lin, W.-C.; Chen, T.-J.; Tsai, S.-J.; Liou, Y.-J.; et al. Posttraumatic stress disorder and risk of osteoporosis: A nationwide longitudinal study. Stress Health 2018, 34, 440-445. [CrossRef] [PubMed]

71. El-Gabalawy, R.; Blaney, C.; Tsai, J.; Sumner, J.A.; Pietrzak, R.H. Physical health conditions associated with full and subthreshold PTSD in U.S. military veterans: Results from the National Health and Resilience in Veterans Study. J. Affect. Disord. 2018, 227, 849-853. [CrossRef]

72. Williams, L.J.; Pasco, J.A.; Jackson, H.; Kiropoulos, L.; Stuart, A.L.; Jacka, F.N.; Berk, M. Depression as a risk factor for fracture in women: A 10 year longitudinal study. J. Affect. Disord. 2016, 192, 34-40. [CrossRef] [PubMed]

73. Yirmiya, R.; Bab, I. Major depression is a risk factor for low bone mineral density: A meta-analysis. Biol. Psychiatry 2009, 66, 423-432. [CrossRef]

74. Wong, S.Y.S.; Lau, E.M.C.; Lynn, H.; Leung, P.C.; Woo, J.; Cummings, S.R.; Orwoll, E. Depression and bone mineral density: Is there a relationship in elderly Asian men? Results from Mr. Os (Hong Kong). Osteoporos. Int. 2005, 16, 610-615. [CrossRef]

75. Schweiger, U.; Deuschle, M.; Körner, A.; Lammers, C.H.; Schmider, J.; Gotthardt, U.; Holsboer, F.; Heuser, I. Low lumbar bone mineral density in patients with major depression. Am. J. Psychiatry 1994, 151, 1691-1693. [CrossRef] 
76. Esel, E.; Ozsoy, S.; Tutus, A.; Sofuoglu, S.; Kartalci, S.; Bayram, F.; Kokbudak, Z.; Kula, M. Effects of antidepressant treatment and of gender on serum leptin levels in patients with major depression. Prog. Neuropsychopharmacol. Biol. Psychiatry 2005, 29, 565-570. [CrossRef] [PubMed]

77. Michelson, D.; Stratakis, C.; Hill, L.; Reynolds, J.; Galliven, E.; Chrousos, G.; Gold, P. Bone mineral density in women with depression. N. Engl. J. Med. 1996, 335, 1176-1181. [CrossRef]

78. Altindag, O.; Altindag, A.; Asoglu, M.; Gunes, M.; Soran, N.; Deveci, Z. Relation of cortisol levels and bone mineral density among premenopausal women with major depression. Int. J. Clin. Pract. 2007, 61, 416-420. [CrossRef] [PubMed]

79. Cosman, F.; Ruffing, J.; Zion, M.; Uhorchak, J.; Ralston, S.; Tendy, S.; McGuigan, F.E.A.; Lindsay, R.; Nieves, J. Determinants of stress fracture risk in United States Military Academy cadets. Bone 2013, 55, 359-366. [CrossRef]

80. Vandewalle, B.; Revillion, F.; Lefebvre, J. Functional beta-adrenergic receptors in breast cancer cells. J. Cancer Res. Clin. Oncol. 1990, 116, 303-306. [CrossRef]

81. Madden, K.S.; Szpunar, M.J.; Brown, E.B. $\beta$-Adrenergic receptors ( $\beta$-AR) regulate VEGF and IL-6 production by divergent pathways in high $\beta$-AR-expressing breast cancer cell lines. Breast Cancer Res. Treat. 2011, 130, 747-758. [CrossRef] [PubMed]

82. Powe, D.G.; Voss, M.J.; Habashy, H.O.; Zänker, K.S.; Green, A.R.; Ellis, I.O.; Entschladen, F. Alpha- and beta-adrenergic receptor (AR) protein expression is associated with poor clinical outcome in breast cancer: An immunohistochemical study. Breast Cancer Res. Treat. 2011, 130, 457-463. [CrossRef]

83. Takeda, S.; Elefteriou, F.; Levasseur, R.; Liu, X.; Zhao, L.; Parker, K.L.; Armstrong, D.; Ducy, P.; Karsenty, G. Leptin regulates bone formation via the sympathetic nervous system. Cell 2002, 111, 305-317. [CrossRef]

84. Elefteriou, F.; Ahn, J.D.; Takeda, S.; Starbuck, M.; Yang, X.; Liu, X.; Kondo, H.; Richards, W.G.; Bannon, T.W.; Noda, M.; et al. Leptin regulation of bone resorption by the sympathetic nervous system and CART. Nature 2005, 434, 514-520. [CrossRef] [PubMed]

85. Kajimura, D.; Hinoi, E.; Ferron, M.; Kode, A.; Riley, K.J.; Zhou, B.; Guo, X.E.; Karsenty, G. Genetic determination of the cellular basis of the sympathetic regulation of bone mass accrual. J. Exp. Med. 2011, 208, 841-851. [CrossRef] [PubMed]

86. Schlienger, R.G.; Kraenzlin, M.E.; Jick, S.S.; Meier, C.R. Use of beta-blockers and risk of fractures. JAMA 2004, 292, 1326-1332. [CrossRef]

87. Meisinger, C.; Heier, M.; Lang, O.; Döring, A. Beta-blocker use and risk of fractures in men and women from the general population: The MONICA/KORA Augsburg cohort study. Osteoporos. Int. 2007, 18, 1189-1195. [CrossRef]

88. Toulis, K.A.; Hemming, K.; Stergianos, S.; Nirantharakumar, K.; Bilezikian, J.P. $\beta$-Adrenergic receptor antagonists and fracture risk: A meta-analysis of selectivity, gender, and site-specific effects. Osteoporos. Int. 2014, 25, 121-129. [CrossRef] [PubMed]

89. Lary, C.W.; Hinton, A.C.; Nevola, K.T.; Shireman, T.I.; Motyl, K.J.; Houseknecht, K.L.; Lucas, F.L.; Hallen, S.; Zullo, A.R.; Berry, S.D.; et al. Association of Beta Blocker Use With Bone Mineral Density in the Framingham Osteoporosis Study: A Cross-Sectional Study. JBMR Plus 2020, 4, e10388. [CrossRef]

90. Turker, S.; Karatosun, V.; Gunal, I. Beta-blockers increase bone mineral density. Clin. Orthop. Relat. Res. 2006, 443, 73-74. [CrossRef]

91. Pasco, J.A.; Henry, M.J.; Sanders, K.M.; Kotowicz, M.A.; Seeman, E.; Nicholson, G.C. Geelong Osteoporosis Study Beta-adrenergic blockers reduce the risk of fracture partly by increasing bone mineral density: Geelong Osteoporosis Study. J. Bone Miner. Res. 2004, 19, 19-24. [CrossRef]

92. Rejnmark, L.; Vestergaard, P.; Mosekilde, L. Treatment with beta-blockers, ACE inhibitors, and calcium-channel blockers is associated with a reduced fracture risk: A nationwide case-control study. J. Hypertens. 2006, 24, 581-589. [CrossRef] [PubMed]

93. Bonnet, N.; Gadois, C.; McCloskey, E.; Lemineur, G.; Lespessailles, E.; Courteix, D.; Benhamou, C.L. Protective effect of beta blockers in postmenopausal women: Influence on fractures, bone density, micro and macroarchitecture. Bone 2007, 40, 1209-1216. [CrossRef]

94. Khosla, S.; Drake, M.T.; Volkman, T.L.; Thicke, B.S.; Achenbach, S.J.; Atkinson, E.J.; Joyner, M.J.; Rosen, C.J.; Monroe, D.G.; Farr, J.N. Sympathetic $\beta 1$-adrenergic signaling contributes to regulation of human bone metabolism. J. Clin. Investig. 2018, 128, 4832-4842. [CrossRef]

95. Grytli, H.H.; Fagerland, M.W.; Fosså, S.D.; Taskén, K.A.; Håheim, L.L. Use of $\beta$-blockers is associated with prostate cancer-specific survival in prostate cancer patients on androgen deprivation therapy. Prostate 2013, 73, 250-260. [CrossRef] [PubMed]

96. Grytli, H.H.; Fagerland, M.W.; Fosså, S.D.; Taskén, K.A. Association between use of $\beta$-blockers and prostate cancer-specific survival: A cohort study of 3561 prostate cancer patients with high-risk or metastatic disease. Eur. Urol. 2014, 65, 635-641. [CrossRef]

97. Watkins, J.L.; Thaker, P.H.; Nick, A.M.; Ramondetta, L.M.; Kumar, S.; Urbauer, D.L.; Matsuo, K.; Squires, K.C.; Coleman, R.L.; Lutgendorf, S.K.; et al. Clinical impact of selective and nonselective beta-blockers on survival in patients with ovarian cancer. Cancer 2015, 121, 3444-3451. [CrossRef] [PubMed]

98. Wang, H.M.; Liao, Z.X.; Komaki, R.; Welsh, J.W.; O’Reilly, M.S.; Chang, J.Y.; Zhuang, Y.; Levy, L.B.; Lu, C.; Gomez, D.R. Improved survival outcomes with the incidental use of beta-blockers among patients with non-small-cell lung cancer treated with definitive radiation therapy. Ann. Oncol. Off. J. Eur. Soc. Med. Oncol. 2013, 24, 1312-1319. [CrossRef] [PubMed]

99. Perron, L.; Bairati, I.; Harel, F.; Meyer, F. Antihypertensive drug use and the risk of prostate cancer (Canada). Cancer Causes Control 2004, 15, 535-541. [CrossRef] [PubMed] 
100. Lemeshow, S.; Sørensen, H.T.; Phillips, G.; Yang, E.V.; Antonsen, S.; Riis, A.H.; Lesinski, G.B.; Jackson, R.; Glaser, R. $\beta$-Blockers and survival among Danish patients with malignant melanoma: A population-based cohort study. Cancer Epidemiol. Biomarkers Prev. 2011, 20, 2273-2279. [CrossRef] [PubMed]

101. Aydiner, A.; Ciftci, R.; Karabulut, S.; Kilic, L. Does beta-blocker therapy improve the survival of patients with metastatic non-small cell lung cancer? Asian Pac. J. Cancer Prev. 2013, 14, 6109-6114. [CrossRef]

102. De Giorgi, V.; Gandini, S.; Grazzini, M.; Benemei, S.; Marchionni, N.; Geppetti, P. Effect of $\beta$-blockers and other antihypertensive drugs on the risk of melanoma recurrence and death. Mayo Clin. Proc. 2013, 88, 1196-1203. [CrossRef]

103. Cardwell, C.R.; Coleman, H.G.; Murray, L.J.; Entschladen, F.; Powe, D.G. Beta-blocker usage and breast cancer survival: A nested case-control study within a UK clinical practice research datalink cohort. Int. J. Epidemiol. 2013, 42, 1852-1861. [CrossRef] [PubMed]

104. Reeder, A.; Attar, M.; Nazario, L.; Bathula, C.; Zhang, A.; Hochbaum, D.; Roy, E.; Cooper, K.L.; Oesterreich, S.; Davidson, N.E.; et al. Stress hormones reduce the efficacy of paclitaxel in triple negative breast cancer through induction of DNA damage. $\mathrm{Br}$. J. Cancer 2015, 112, 1461-1470. [CrossRef]

105. Hara, M.R.; Sachs, B.D.; Caron, M.G.; Lefkowitz, R.J. Pharmacological blockade of a $\beta(2)$ AR- $\beta$-arrestin- 1 signaling cascade prevents the accumulation of DNA damage in a behavioral stress model. Cell Cycle 2013, 12, 219-224. [CrossRef]

106. Hara, M.R.; Kovacs, J.J.; Whalen, E.J.; Rajagopal, S.; Strachan, R.T.; Grant, W.; Towers, A.J.; Williams, B.; Lam, C.M.; Xiao, K.; et al. A stress response pathway regulates DNA damage through $\beta 2$-adrenoreceptors and $\beta$-arrestin-1. Nature 2011, 477, 349-353. [CrossRef] [PubMed]

107. Armaiz-Pena, G.N.; Allen, J.K.; Cruz, A.; Stone, R.L.; Nick, A.M.; Lin, Y.G.; Han, L.Y.; Mangala, L.S.; Villares, G.J.; Vivas-Mejia, P.; et al. Src activation by $\beta$-adrenoreceptors is a key switch for tumour metastasis. Nat. Commun. 2013, 4, 1403. [CrossRef] [PubMed]

108. Shi, M.; Liu, D.; Duan, H.; Qian, L.; Wang, L.; Niu, L.; Zhang, H.; Yong, Z.; Gong, Z.; Song, L.; et al. The $\beta 2$-adrenergic receptor and Her2 comprise a positive feedback loop in human breast cancer cells. Breast Cancer Res. Treat. 2011, 125, 351-362. [CrossRef]

109. Gu, L.; Lau, S.K.; Loera, S.; Somlo, G.; Kane, S.E. Protein kinase A activation confers resistance to trastuzumab in human breast cancer cell lines. Clin. Cancer Res. 2009, 15, 7196-7206. [CrossRef] [PubMed]

110. Hassan, S.; Karpova, Y.; Baiz, D.; Yancey, D.; Pullikuth, A.; Flores, A.; Register, T.; Cline, J.M.; D’Agostino, R.; Danial, N.; et al. Behavioral stress accelerates prostate cancer development in mice. J. Clin. Investig. 2013, 123, 874-886. [CrossRef]

111. Sastry, K.S.R.; Karpova, Y.; Prokopovich, S.; Smith, A.J.; Essau, B.; Gersappe, A.; Carson, J.P.; Weber, M.J.; Register, T.C.; Chen, Y.Q.; et al. Epinephrine protects cancer cells from apoptosis via activation of cAMP-dependent protein kinase and BAD phosphorylation. J. Biol. Chem. 2007, 282, 14094-14100. [CrossRef] [PubMed]

112. Pasquier, E.; Street, J.; Pouchy, C.; Carre, M.; Gifford, A.J.; Murray, J.; Norris, M.D.; Trahair, T.; Andre, N.; Kavallaris, M. $\beta$-blockers increase response to chemotherapy via direct antitumour and anti-angiogenic mechanisms in neuroblastoma. Br. J. Cancer 2013, 108, 2485-2494. [CrossRef] [PubMed]

113. Wolter, J.K.; Wolter, N.E.; Blanch, A.; Partridge, T.; Cheng, L.; Morgenstern, D.A.; Podkowa, M.; Kaplan, D.R.; Irwin, M.S. Antitumor activity of the beta-adrenergic receptor antagonist propranolol in neuroblastoma. Oncotarget 2014, 5, 161-172. [CrossRef] [PubMed]

114. Drell, T.L.; Joseph, J.; Lang, K.; Niggemann, B.; Zaenker, K.S.; Entschladen, F. Effects of neurotransmitters on the chemokinesis and chemotaxis of MDA-MB-468 human breast carcinoma cells. Breast Cancer Res. Treat. 2003, 80, 63-70. [CrossRef]

115. Lutgendorf, S.K.; Cole, S.; Costanzo, E.; Bradley, S.; Coffin, J.; Jabbari, S.; Rainwater, K.; Ritchie, J.M.; Yang, M.; Sood, A.K. Stress-related mediators stimulate vascular endothelial growth factor secretion by two ovarian cancer cell lines. Clin. Cancer Res. 2003, 9, 4514-4521. [PubMed]

116. Nilsson, M.B.; Armaiz-Pena, G.; Takahashi, R.; Lin, Y.G.; Trevino, J.; Li, Y.; Jennings, N.; Arevalo, J.; Lutgendorf, S.K.; Gallick, G.E.; et al. Stress hormones regulate interleukin-6 expression by human ovarian carcinoma cells through a Src-dependent mechanism. J. Biol. Chem. 2007, 282, 29919-29926. [CrossRef] [PubMed]

117. Lang, K.; Drell, T.L.; Lindecke, A.; Niggemann, B.; Kaltschmidt, C.; Zaenker, K.S.; Entschladen, F. Induction of a metastatogenic tumor cell type by neurotransmitters and its pharmacological inhibition by established drugs. Int. J. Cancer 2004, 112, 231-238. [CrossRef]

118. Pérez Piñero, C.; Bruzzone, A.; Sarappa, M.G.; Castillo, L.F.; Lüthy, I.A. Involvement of $\alpha 2$ - and $\beta 2$-adrenoceptors on breast cancer cell proliferation and tumour growth regulation. Br. J. Pharmacol. 2012, 166, 721-736. [CrossRef]

119. Slotkin, T.A.; Zhang, J.; Dancel, R.; Garcia, S.J.; Willis, C.; Seidler, F.J. Beta-adrenoceptor signaling and its control of cell replication in MDA-MB-231 human breast cancer cells. Breast Cancer Res. Treat. 2000, 60, 153-166. [CrossRef]

120. Gargiulo, L.; Copsel, S.; Rivero, E.M.; Galés, C.; Sénard, J.-M.; Lüthy, I.A.; Davio, C.; Bruzzone, A. Differential $\beta_{2}$-adrenergic receptor expression defines the phenotype of non-tumorigenic and malignant human breast cell lines. Oncotarget 2014, 5, 10058-10069. [CrossRef]

121. Liu, D.; Deng, Q.; Sun, L.; Wang, T.; Yang, Z.; Chen, H.; Guo, L.; Liu, Y.; Ma, Y.; Guo, N.; et al. A Her2-let-7- $\beta 2-A R$ circuit affects prognosis in patients with Her2-positive breast cancer. BMC Cancer 2015, 15, 832. [CrossRef]

122. Rivero, E.M.; Martinez, L.M.; Bruque, C.D.; Gargiulo, L.; Bruzzone, A.; Lüthy, I.A. Prognostic significance of $\alpha$ - and $\beta 2-$ adrenoceptor gene expression in breast cancer patients. Br. J. Clin. Pharmacol. 2019, 85, 2143-2154. [CrossRef] [PubMed] 
123. Kurozumi, S.; Kaira, K.; Matsumoto, H.; Hirakata, T.; Yokobori, T.; Inoue, K.; Horiguchi, J.; Katayama, A.; Koshi, H.; Shimizu, A.; et al. $\beta 2$-Adrenergic receptor expression is associated with biomarkers of tumor immunity and predicts poor prognosis in estrogen receptor-negative breast cancer. Breast Cancer Res. Treat. 2019, 177, 603-610. [CrossRef] [PubMed]

124. Caparica, R.; Richard, F.; Brandão, M.; Awada, A.; Sotiriou, C.; de Azambuja, E. Prognostic and Predictive Impact of Beta-2 Adrenergic Receptor Expression in HER2-Positive Breast Cancer. Clin. Breast Cancer 2020, 20, 262-273.e7. [CrossRef] [PubMed]

125. Pacholczyk, T.; Blakely, R.D.; Amara, S.G. Expression cloning of a cocaine- and antidepressant-sensitive human noradrenaline transporter. Nature 1991, 350, 350-354. [CrossRef]

126. Zavosh, A.; Schaefer, J.; Ferrel, A.; Figlewicz, D.P. Desipramine treatment decreases 3H-nisoxetine binding and norepinephrine transporter mRNA in SK-N-SHSY5Y cells. Brain Res. Bull. 1999, 49, 291-295. [CrossRef]

127. Tellioglu, T.; Robertson, D. Genetic or acquired deficits in the norepinephrine transporter: Current understanding of clinical implications. Expert Rev. Mol. Med. 2001, 2001,1-10. [CrossRef]

128. Blakely, R.D.; Bauman, A.L. Biogenic amine transporters: Regulation in flux. Curr. Opin. Neurobiol. 2000, 10, 328-336. [CrossRef]

129. Ma, Y.; Krueger, J.J.; Redmon, S.N.; Uppuganti, S.; Nyman, J.S.; Hahn, M.K.; Elefteriou, F. Extracellular norepinephrine clearance by the norepinephrine transporter is required for skeletal homeostasis. J. Biol. Chem. 2013, 288, 30105-30113. [CrossRef]

130. Zhu, Y.; Ma, Y.; Elefteriou, F. Cortical bone is an extraneuronal site of norepinephrine uptake in adult mice. Bone Rep. 2018, 9 , 188-198. [CrossRef]

131. Mohammadpour, H.; MacDonald, C.R.; Qiao, G.; Chen, M.; Dong, B.; Hylander, B.L.; McCarthy, P.L.; Abrams, S.I.; Repasky, E.A. $\beta 2$ adrenergic receptor-mediated signaling regulates the immunosuppressive potential of myeloid-derived suppressor cells. $J$. Clin. Investig. 2019, 129, 5537-5552. [CrossRef]

132. Sloan, E.K.; Priceman, S.J.; Cox, B.F.; Yu, S.; Pimentel, M.A.; Tangkanangnukul, V.; Arevalo, J.M.G.; Morizono, K.; Karanikolas, B.D.W.; $\mathrm{Wu}, \mathrm{L} . ;$ et al. The sympathetic nervous system induces a metastatic switch in primary breast cancer. Cancer Res. 2010, 70 7042-7052. [CrossRef] [PubMed]

133. Armaiz-Pena, G.N.; Gonzalez-Villasana, V.; Nagaraja, A.S.; Rodriguez-Aguayo, C.; Sadaoui, N.C.; Stone, R.L.; Matsuo, K.; Dalton, H.J.; Previs, R.A.; Jennings, N.B.; et al. Adrenergic regulation of monocyte chemotactic protein 1 leads to enhanced macrophage recruitment and ovarian carcinoma growth. Oncotarget 2015, 6, 4266-4273. [CrossRef] [PubMed]

134. Cole, S.W.; Korin, Y.D.; Fahey, J.L.; Zack, J.A. Norepinephrine accelerates HIV replication via protein kinase A-dependent effects on cytokine production. J. Immunol. 1998, 161, 610-616. [PubMed]

135. Collado-Hidalgo, A.; Sung, C.; Cole, S. Adrenergic inhibition of innate anti-viral response: PKA blockade of Type I interferon gene transcription mediates catecholamine support for HIV-1 replication. Brain Behav. Immun. 2006, 20, 552-563. [CrossRef] [PubMed]

136. Inbar, S.; Neeman, E.; Avraham, R.; Benish, M.; Rosenne, E.; Ben-Eliyahu, S. Do stress responses promote leukemia progression? An animal study suggesting a role for epinephrine and prostaglandin-E2 through reduced NK activity. PLoS ONE 2011, 6, e19246. [CrossRef]

137. Goldfarb, Y.; Sorski, L.; Benish, M.; Levi, B.; Melamed, R.; Ben-Eliyahu, S. Improving postoperative immune status and resistance to cancer metastasis: A combined perioperative approach of immunostimulation and prevention of excessive surgical stress responses. Ann. Surg. 2011, 253, 798-810. [CrossRef]

138. Lee, J.-W.; Shahzad, M.M.K.; Lin, Y.G.; Armaiz-Pena, G.; Mangala, L.S.; Han, H.-D.; Kim, H.-S.; Nam, E.J.; Jennings, N.B.; Halder, J.; et al. Surgical stress promotes tumor growth in ovarian carcinoma. Clin. Cancer Res. 2009, 15, 2695-2702. [CrossRef]

139. Glasner, A.; Avraham, R.; Rosenne, E.; Benish, M.; Zmora, O.; Shemer, S.; Meiboom, H.; Ben-Eliyahu, S. Improving survival rates in two models of spontaneous postoperative metastasis in mice by combined administration of a beta-adrenergic antagonist and a cyclooxygenase-2 inhibitor. J. Immunol. 2010, 184, 2449-2457. [CrossRef]

140. Magnon, C.; Hall, S.J.; Lin, J.; Xue, X.; Gerber, L.; Freedland, S.J.; Frenette, P.S. Autonomic nerve development contributes to prostate cancer progression. Science 2013, 341, 1236361. [CrossRef]

141. Campbell, J.P.; Karolak, M.R.; Ma, Y.; Perrien, D.S.; Masood-Campbell, S.K.; Penner, N.L.; Munoz, S.A.; Zijlstra, A.; Yang, X.; Sterling, J.A.; et al. Stimulation of host bone marrow stromal cells by sympathetic nerves promotes breast cancer bone metastasis in mice. PLoS Biol. 2012, 10, e1001363. [CrossRef] [PubMed]

142. Katayama, Y.; Battista, M.; Kao, W.-M.; Hidalgo, A.; Peired, A.J.; Thomas, S.A.; Frenette, P.S. Signals from the sympathetic nervous system regulate hematopoietic stem cell egress from bone marrow. Cell 2006, 124, 407-421. [CrossRef] [PubMed]

143. Zheng, H.; Fu, G.; Dai, T.; Huang, H. Migration of endothelial progenitor cells mediated by stromal cell-derived factor1alpha/CXCR4 via PI3K/Akt/eNOS signal transduction pathway. J. Cardiovasc. Pharmacol. 2007, 50, 274-280. [CrossRef]

144. Elefteriou, F. Regulation of bone remodeling by the central and peripheral nervous system. Arch. Biochem. Biophys. 2008, 473, 231-236. [CrossRef]

145. Yao, Q.; Liang, H.; Huang, B.; Xiang, L.; Wang, T.; Xiong, Y.; Yang, B.; Guo, Y.; Gong, P. Beta-adrenergic signaling affect osteoclastogenesis via osteocytic MLO-Y4 cells' RANKL production. Biochem. Biophys. Res. Commun. 2017, 488, 634-640. [CrossRef]

146. Jiao, K.; Niu, L.-N.; Li, Q.; Ren, G.; Zhao, C.; Liu, Y.; Tay, F.R.; Wang, M. $\beta 2$-Adrenergic signal transduction plays a detrimental role in subchondral bone loss of temporomandibular joint in osteoarthritis. Sci. Rep. 2015, 5, 12593. [CrossRef]

147. Ferrara, N.; Davis-Smyth, T. The biology of vascular endothelial growth factor. Endocr. Rev. 1997, 18, 4-25. [CrossRef] 
148. Achen, M.G.; Jeltsch, M.; Kukk, E.; Mäkinen, T.; Vitali, A.; Wilks, A.F.; Alitalo, K.; Stacker, S.A. Vascular endothelial growth factor $\mathrm{D}$ (VEGF-D) is a ligand for the tyrosine kinases VEGF receptor 2 (Flk1) and VEGF receptor 3 (Flt4). Proc. Natl. Acad. Sci. USA 1998, 95, 548-553. [CrossRef]

149. Ogawa, S.; Oku, A.; Sawano, A.; Yamaguchi, S.; Yazaki, Y.; Shibuya, M. A novel type of vascular endothelial growth factor, VEGF-E (NZ-7 VEGF), preferentially utilizes KDR/Flk-1 receptor and carries a potent mitotic activity without heparin-binding domain. J. Biol. Chem. 1998, 273, 31273-31282. [CrossRef]

150. Meyer, M.; Clauss, M.; Lepple-Wienhues, A.; Waltenberger, J.; Augustin, H.G.; Ziche, M.; Lanz, C.; Büttner, M.; Rziha, H.J.; Dehio, C. A novel vascular endothelial growth factor encoded by Orf virus, VEGF-E, mediates angiogenesis via signalling through VEGFR-2 (KDR) but not VEGFR-1 (Flt-1) receptor tyrosine kinases. EMBO J. 1999, 18, 363-374. [CrossRef] [PubMed]

151. Weidner, N.; Semple, J.P.; Welch, W.R.; Folkman, J. Tumor angiogenesis and metastasis-Correlation in invasive breast carcinoma. N. Engl. J. Med. 1991, 324, 1-8. [CrossRef]

152. Yang, E.V.; Kim, S.; Donovan, E.L.; Chen, M.; Gross, A.C.; Webster Marketon, J.I.; Barsky, S.H.; Glaser, R. Norepinephrine upregulates VEGF, IL-8, and IL-6 expression in human melanoma tumor cell lines: Implications for stress-related enhancement of tumor progression. Brain Behav. Immun. 2009, 23, 267-275. [CrossRef]

153. Liu, J.; Deng, G.-H.; Zhang, J.; Wang, Y.; Xia, X.-Y.; Luo, X.-M.; Deng, Y.-T.; He, S.-S.; Mao, Y.-Y.; Peng, X.-C.; et al. The effect of chronic stress on anti-angiogenesis of sunitinib in colorectal cancer models. Psychoneuroendocrinology 2015, 52, 130-142. [CrossRef] [PubMed]

154. Xie, H.; Li, C.; He, Y.; Griffin, R.; Ye, Q.; Li, L. Chronic stress promotes oral cancer growth and angiogenesis with increased circulating catecholamine and glucocorticoid levels in a mouse model. Oral Oncol. 2015, 51, 991-997. [CrossRef] [PubMed]

155. Kusumbe, A.P.; Ramasamy, S.K.; Adams, R.H. Coupling of angiogenesis and osteogenesis by a specific vessel subtype in bone. Nature 2014, 507, 323-328. [CrossRef] [PubMed]

156. Kusumbe, A.P.; Ramasamy, S.K.; Itkin, T.; Mäe, M.A.; Langen, U.H.; Betsholtz, C.; Lapidot, T.; Adams, R.H. Age-dependent modulation of vascular niches for haematopoietic stem cells. Nature 2016, 532, 380-384. [CrossRef]

157. Mulcrone, P.L.; Campbell, J.P.; Clément-Demange, L.; Anbinder, A.L.; Merkel, A.R.; Brekken, R.A.; Sterling, J.A.; Elefteriou, F.

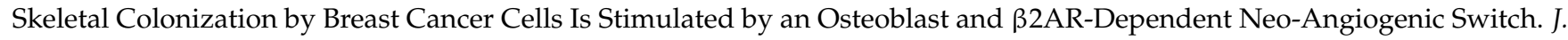
Bone Miner. Res. 2017, 32, 1442-1454. [CrossRef]

158. Clément-Demange, L.; Mulcrone, P.L.; Tabarestani, T.Q.; Sterling, J.A.; Elefteriou, F. $\beta 2$ ARs stimulation in osteoblasts promotes breast cancer cell adhesion to bone marrow endothelial cells in an IL-1 $\beta$ and selectin-dependent manner. J. Bone Oncol. 2018, 13, 1-10. [CrossRef]

159. Gopinathan, G.; Milagre, C.; Pearce, O.M.T.; Reynolds, L.E.; Hodivala-Dilke, K.; Leinster, D.A.; Zhong, H.; Hollingsworth, R.E.; Thompson, R.; Whiteford, J.R.; et al. Interleukin-6 Stimulates Defective Angiogenesis. Cancer Res. 2015, 75, 3098-3107. [CrossRef]

160. Catar, R.; Witowski, J.; Zhu, N.; Lücht, C.; Derrac Soria, A.; Uceda Fernandez, J.; Chen, L.; Jones, S.A.; Fielding, C.A.; Rudolf, A.; et al. IL-6 Trans-Signaling Links Inflammation with Angiogenesis in the Peritoneal Membrane. J. Am. Soc. Nephrol. 2017, 28, 1188-1199. [CrossRef]

161. Shinriki, S.; Jono, H.; Ueda, M.; Ota, K.; Ota, T.; Sueyoshi, T.; Oike, Y.; Ibusuki, M.; Hiraki, A.; Nakayama, H.; et al. Interleukin6 signalling regulates vascular endothelial growth factor-C synthesis and lymphangiogenesis in human oral squamous cell carcinoma. J. Pathol. 2011, 225, 142-150. [CrossRef]

162. Jiang, X.-P.; Yang, D.C.; Elliott, R.L.; Head, J.F. Down-regulation of expression of interleukin-6 and its receptor results in growth inhibition of MCF-7 breast cancer cells. Anticancer Res. 2011, 31, 2899-2906.

163. Studebaker, A.W.; Storci, G.; Werbeck, J.L.; Sansone, P.; Sasser, A.K.; Tavolari, S.; Huang, T.; Chan, M.W.Y.; Marini, F.C.; Rosol, T.J.; et al. Fibroblasts isolated from common sites of breast cancer metastasis enhance cancer cell growth rates and invasiveness in an interleukin-6-dependent manner. Cancer Res. 2008, 68, 9087-9095. [CrossRef]

164. Strilic, B.; Offermanns, S. Intravascular Survival and Extravasation of Tumor Cells. Cancer Cell 2017, 32, 282-293. [CrossRef]

165. Biancone, L.; Araki, M.; Araki, K.; Vassalli, P.; Stamenkovic, I. Redirection of tumor metastasis by expression of E-selectin in vivo. J. Exp. Med. 1996, 183, 581-587. [CrossRef] [PubMed]

166. Bendas, G.; Borsig, L. Cancer cell adhesion and metastasis: Selectins, integrins, and the inhibitory potential of heparins. Int. J. Cell Biol. 2012, 2012, 676731. [CrossRef]

167. Sökeland, G.; Schumacher, U. The functional role of integrins during intra- and extravasation within the metastatic cascade. Mol. Cancer 2019, 18, 12. [CrossRef] [PubMed]

168. Makó, V.; Czúcz, J.; Weiszhár, Z.; Herczenik, E.; Matkó, J.; Prohászka, Z.; Cervenak, L. Proinflammatory activation pattern of human umbilical vein endothelial cells induced by IL-1 $\beta$, TNF- $\alpha$, and LPS. Cytometry A 2010, 77, 962-970. [CrossRef] [PubMed]

169. Bokhari, S.M.; Zhou, L.; Karasek, M.A.; Paturi, S.G.; Chaudhuri, V. Regulation of skin microvasculature angiogenesis, cell migration, and permeability by a specific inhibitor of PKCalpha. J. Investig. Dermatol. 2006, 126, 460-467. [CrossRef] [PubMed]

170. Voronov, E.; Dotan, S.; Krelin, Y.; Song, X.; Elkabets, M.; Carmi, Y.; Rider, P.; Idan, C.; Romzova, M.; Kaplanov, I.; et al. Unique Versus Redundant Functions of IL-1 $\alpha$ and IL-1 $\beta$ in the Tumor Microenvironment. Front. Immunol. 2013, 4, 177. [CrossRef]

171. Khatib, A.-M.; Auguste, P.; Fallavollita, L.; Wang, N.; Samani, A.; Kontogiannea, M.; Meterissian, S.; Brodt, P. Characterization of the host proinflammatory response to tumor cells during the initial stages of liver metastasis. Am. J. Pathol. 2005, 167, 749-759. [CrossRef] 
172. Okahara, H.; Yagita, H.; Miyake, K.; Okumura, K. Involvement of very late activation antigen 4 (VLA-4) and vascular cell adhesion molecule 1 (VCAM-1) in tumor necrosis factor alpha enhancement of experimental metastasis. Cancer Res. 1994, 54, 3233-3236. [PubMed]

173. Giavazzi, R.; Garofalo, A.; Bani, M.R.; Abbate, M.; Ghezzi, P.; Boraschi, D.; Mantovani, A.; Dejana, E. Interleukin 1-induced augmentation of experimental metastases from a human melanoma in nude mice. Cancer Res. 1990, 50, 4771-4775. [PubMed]

174. Lauri, D.; Bertomeu, M.C.; Orr, F.W.; Bastida, E.; Sauder, D.; Buchanan, M.R. Interleukin-1 increases tumor cell adhesion to endothelial cells through an RGD dependent mechanism: In vitro and in vivo studies. Clin. Exp. Metastasis 1990, 8, 27-32. [CrossRef]

175. Arguello, F.; Baggs, R.B.; Graves, B.T.; Harwell, S.E.; Cohen, H.J.; Frantz, C.N. Effect of IL-1 on experimental bone/bone-marrow metastases. Int. J. Cancer 1992, 52, 802-807. [CrossRef]

176. Voronov, E.; Shouval, D.S.; Krelin, Y.; Cagnano, E.; Benharroch, D.; Iwakura, Y.; Dinarello, C.A.; Apte, R.N. IL-1 is required for tumor invasiveness and angiogenesis. Proc. Natl. Acad. Sci. USA 2003, 100, 2645-2650. [CrossRef]

177. Udagawa, N.; Takahashi, N.; Jimi, E.; Matsuzaki, K.; Tsurukai, T.; Itoh, K.; Nakagawa, N.; Yasuda, H.; Goto, M.; Tsuda, E.; et al Osteoblasts/stromal cells stimulate osteoclast activation through expression of osteoclast differentiation factor/RANKL but not macrophage colony-stimulating factor: Receptor activator of NF-kappa B ligand. Bone 1999, 25, 517-523. [CrossRef]

178. Tatsumi, S.; Ishii, K.; Amizuka, N.; Li, M.; Kobayashi, T.; Kohno, K.; Ito, M.; Takeshita, S.; Ikeda, K. Targeted ablation of osteocytes induces osteoporosis with defective mechanotransduction. Cell Metab. 2007, 5, 464-475. [CrossRef] [PubMed]

179. Horwood, N.J.; Kartsogiannis, V.; Quinn, J.M.; Romas, E.; Martin, T.J.; Gillespie, M.T. Activated T lymphocytes support osteoclast formation in vitro. Biochem. Biophys. Res. Commun. 1999, 265, 144-150. [CrossRef]

180. Komuro, H.; Olee, T.; Kühn, K.; Quach, J.; Brinson, D.C.; Shikhman, A.; Valbracht, J.; Creighton-Achermann, L.; Lotz, M. The osteoprotegerin/receptor activator of nuclear factor kappaB/receptor activator of nuclear factor kappaB ligand system in cartilage. Arthritis Rheum. 2001, 44, 2768-2776. [CrossRef]

181. Kwan Tat, S.; Amiable, N.; Pelletier, J.-P.; Boileau, C.; Lajeunesse, D.; Duval, N.; Martel-Pelletier, J. Modulation of OPG, RANK and RANKL by human chondrocytes and their implication during osteoarthritis. Rheumatology 2009, 48, 1482-1490. [CrossRef] [PubMed]

182. Feng, X.; Teitelbaum, S.L. Osteoclasts: New Insights. Bone Res. 2013, 1, 11-26. [CrossRef] [PubMed]

183. Jones, D.H.; Nakashima, T.; Sanchez, O.H.; Kozieradzki, I.; Komarova, S.V.; Sarosi, I.; Morony, S.; Rubin, E.; Sarao, R.; Hojilla, C.V.; et al. Regulation of cancer cell migration and bone metastasis by RANKL. Nature 2006, 440, 692-696. [CrossRef]

184. Chen, L.-M.; Kuo, C.-H.; Lai, T.-Y.; Lin, Y.-M.; Su, C.-C.; Hsu, H.-H.; Tsai, F.-J.; Tsai, C.-H.; Huang, C.-Y.; Tang, C.-H. RANKL increases migration of human lung cancer cells through intercellular adhesion molecule-1 up-regulation. J. Cell. Biochem. 2011, 112, 933-941. [CrossRef]

185. Armstrong, A.P.; Miller, R.E.; Jones, J.C.; Zhang, J.; Keller, E.T.; Dougall, W.C. RANKL acts directly on RANK-expressing prostate tumor cells and mediates migration and expression of tumor metastasis genes. Prostate 2008, 68, 92-104. [CrossRef]

186. Zhang, L.; Teng, Y.; Zhang, Y.; Liu, J.; Xu, L.; Qu, J.; Hou, K.; Yang, X.; Liu, Y.; Qu, X. Receptor activator for nuclear factor k B expression predicts poor prognosis in breast cancer patients with bone metastasis but not in patients with visceral metastasis. $J$. Clin. Pathol. 2012, 65, 36-40. [CrossRef] [PubMed]

187. Ibrahim, T.; Sacanna, E.; Gaudio, M.; Mercatali, L.; Scarpi, E.; Zoli, W.; Serra, P.; Ricci, R.; Serra, L.; Kang, Y.; et al. Role of RANK, RANKL, OPG, and CXCR4 tissue markers in predicting bone metastases in breast cancer patients. Clin. Breast Cancer 2011, 11, 369-375. [CrossRef]

188. Nakashima, T.; Hayashi, M.; Fukunaga, T.; Kurata, K.; Oh-Hora, M.; Feng, J.Q.; Bonewald, L.F.; Kodama, T.; Wutz, A.; Wagner, E.F.; et al. Evidence for osteocyte regulation of bone homeostasis through RANKL expression. Nat. Med. 2011, 17, 1231-1234. [CrossRef]

189. Axmann, R.; Böhm, C.; Krönke, G.; Zwerina, J.; Smolen, J.; Schett, G. Inhibition of interleukin-6 receptor directly blocks osteoclast formation in vitro and in vivo. Arthritis Rheum. 2009, 60, 2747-2756. [CrossRef]

190. Kudo, O.; Sabokbar, A.; Pocock, A.; Itonaga, I.; Fujikawa, Y.; Athanasou, N.A. Interleukin-6 and interleukin-11 support human osteoclast formation by a RANKL-independent mechanism. Bone 2003, 32, 1-7. [CrossRef]

191. Devlin, R.D.; Reddy, S.V.; Savino, R.; Ciliberto, G.; Roodman, G.D. IL-6 mediates the effects of IL-1 or TNF, but not PTHrP or 1,25(OH)2D3, on osteoclast-like cell formation in normal human bone marrow cultures. J. Bone Miner. Res. 1998, 13, 393-399. [CrossRef] [PubMed]

192. Elefteriou, F. Neuronal signaling and the regulation of bone remodeling. Cell. Mol. Life Sci. 2005, 62, 2339-2349. [CrossRef] [PubMed]

193. Aitken, S.J.; Landao-Bassonga, E.; Ralston, S.H.; Idris, A.I. Beta2-adrenoreceptor ligands regulate osteoclast differentiation in vitro by direct and indirect mechanisms. Arch. Biochem. Biophys. 2009, 482, 96-103. [CrossRef] [PubMed]

194. Arai, M.; Nagasawa, T.; Koshihara, Y.; Yamamoto, S.; Togari, A. Effects of beta-adrenergic agonists on bone-resorbing activity in human osteoclast-like cells. Biochim. Biophys. Acta 2003, 1640, 137-142. [CrossRef]

195. Sanders, J.L.; Chattopadhyay, N.; Kifor, O.; Yamaguchi, T.; Butters, R.R.; Brown, E.M. Extracellular calcium-sensing receptor expression and its potential role in regulating parathyroid hormone-related peptide secretion in human breast cancer cell lines. Endocrinology 2000, 141, 4357-4364. [CrossRef] 
196. Mundy, G.R. Metastasis to bone: Causes, consequences and therapeutic opportunities. Nat. Rev. Cancer 2002, 2, 584-593. [CrossRef]

197. Guise, T.A.; Yin, J.J.; Taylor, S.D.; Kumagai, Y.; Dallas, M.; Boyce, B.F.; Yoneda, T.; Mundy, G.R. Evidence for a causal role of parathyroid hormone-related protein in the pathogenesis of human breast cancer-mediated osteolysis. J. Clin. Investig. 1996, 98, 1544-1549. [CrossRef]

198. Weilbaecher, K.N.; Guise, T.A.; McCauley, L.K. Cancer to bone: A fatal attraction. Nat. Rev. Cancer 2011, 11, 411-425. [CrossRef]

199. Kagiya, T. MicroRNAs and Osteolytic Bone Metastasis: The Roles of MicroRNAs in Tumor-Induced Osteoclast Differentiation. J. Clin. Med. 2015, 4, 1741-1752. [CrossRef]

200. Chiechi, A.; Waning, D.L.; Stayrook, K.R.; Buijs, J.T.; Guise, T.A.; Mohammad, K.S. Role of TGF- $\beta$ in breast cancer bone metastases. Adv. Biosci. Biotechnol. 2013, 4, 15-30. [CrossRef]

201. Kakonen, S.-M.; Selander, K.S.; Chirgwin, J.M.; Yin, J.J.; Burns, S.; Rankin, W.A.; Grubbs, B.G.; Dallas, M.; Cui, Y.; Guise, T.A. Transforming growth factor-beta stimulates parathyroid hormone-related protein and osteolytic metastases via Smad and mitogen-activated protein kinase signaling pathways. J. Biol. Chem. 2002, 277, 24571-24578. [CrossRef] [PubMed]

202. Buijs, J.T.; Stayrook, K.R.; Guise, T.A. TGF- $\beta$ in the Bone Microenvironment: Role in Breast Cancer Metastases. Cancer Microenviron. 2011, 4, 261-281. [CrossRef] [PubMed]

203. Yin, J.J.; Selander, K.; Chirgwin, J.M.; Dallas, M.; Grubbs, B.G.; Wieser, R.; Massagué, J.; Mundy, G.R.; Guise, T.A. TGF-beta signaling blockade inhibits PTHrP secretion by breast cancer cells and bone metastases development. J. Clin. Investig. 1999, 103, 197-206. [CrossRef] [PubMed]

204. Biswas, S.; Nyman, J.S.; Alvarez, J.; Chakrabarti, A.; Ayres, A.; Sterling, J.; Edwards, J.; Rana, T.; Johnson, R.; Perrien, D.S.; et al. Anti-transforming growth factor $ß$ antibody treatment rescues bone loss and prevents breast cancer metastasis to bone. PLoS ONE 2011, 6, e27090. [CrossRef]

205. Ganapathy, V.; Ge, R.; Grazioli, A.; Xie, W.; Banach-Petrosky, W.; Kang, Y.; Lonning, S.; McPherson, J.; Yingling, J.M.; Biswas, S.; et al. Targeting the Transforming Growth Factor-beta pathway inhibits human basal-like breast cancer metastasis. Mol. Cancer 2010, 9, 122. [CrossRef] [PubMed]

206. Korpal, M.; Yan, J.; Lu, X.; Xu, S.; Lerit, D.A.; Kang, Y. Imaging transforming growth factor-beta signaling dynamics and therapeutic response in breast cancer bone metastasis. Nat. Med. 2009, 15, 960-966. [CrossRef]

207. Guise, T.A.; Mundy, G.R. Cancer and Bone*. Endocr. Rev. 1998, 19, 18-54. [CrossRef] [PubMed]

208. Guise, T.A.; Chirgwin, J.M. Transforming growth factor-beta in osteolytic breast cancer bone metastases. Clin. Orthop. Relat. Res. 2003, S32-S38. [CrossRef]

209. Waning, D.L.; Mohammad, K.S.; Reiken, S.; Xie, W.; Andersson, D.C.; John, S.; Chiechi, A.; Wright, L.E.; Umanskaya, A.; Niewolna, M.; et al. Excess TGF- $\beta$ mediates muscle weakness associated with bone metastases in mice. Nat. Med. 2015, 21, 1262-1271. [CrossRef]

210. Regan, J.N.; Mikesell, C.; Reiken, S.; Xu, H.; Marks, A.R.; Mohammad, K.S.; Guise, T.A.; Waning, D.L. Osteolytic Breast Cancer Causes Skeletal Muscle Weakness in an Immunocompetent Syngeneic Mouse Model. Front. Endocrinol. 2017, 8, 358. [CrossRef]

211. Regan, J.N.; Trivedi, T.; Guise, T.A.; Waning, D.L. The Role of TGF $\beta$ in Bone-Muscle Crosstalk. Curr. Osteoporos. Rep. 2017, 15, 18-23. [CrossRef] [PubMed]

212. Madel, M.-B.; Ibáñez, L.; Wakkach, A.; de Vries, T.J.; Teti, A.; Apparailly, F.; Blin-Wakkach, C. Immune Function and Diversity of Osteoclasts in Normal and Pathological Conditions. Front. Immunol. 2019, 10, 1408. [CrossRef]

213. Ibáñez, L.; Abou-Ezzi, G.; Ciucci, T.; Amiot, V.; Belaïd, N.; Obino, D.; Mansour, A.; Rouleau, M.; Wakkach, A.; Blin-Wakkach, C. Inflammatory Osteoclasts Prime TNF $\alpha$-Producing CD4+ T Cells and Express CX3 CR1. J. Bone Miner. Res. 2016, 31, 1899-1908. [CrossRef] [PubMed]

214. Buchwald, Z.S.; Kiesel, J.R.; DiPaolo, R.; Pagadala, M.S.; Aurora, R. Osteoclast activated FoxP3+ CD8+ T-cells suppress bone resorption in vitro. PLoS ONE 2012, 7, e38199. [CrossRef]

215. Kiesel, J.R.; Buchwald, Z.S.; Aurora, R. Cross-presentation by osteoclasts induces FoxP3 in CD8+ T cells. J. Immunol. 2009, 182, 5477-5487. [CrossRef]

216. Madel, M.-B.; Ibáñez, L.; Ciucci, T.; Halper, J.; Rouleau, M.; Boutin, A.; Hue, C.; Duroux-Richard, I.; Apparailly, F.; Garchon, H.-J.; et al. Dissecting the phenotypic and functional heterogeneity of mouse inflammatory osteoclasts by the expression of $\mathrm{Cx} 3 \mathrm{cr} 1$. Elife 2020, 9. [CrossRef] [PubMed]

217. An, G.; Acharya, C.; Feng, X.; Wen, K.; Zhong, M.; Zhang, L.; Munshi, N.C.; Qiu, L.; Tai, Y.-T.; Anderson, K.C. Osteoclasts promote immune suppressive microenvironment in multiple myeloma: Therapeutic implication. Blood 2016, 128, 1590-1603. [CrossRef]

218. Ell, B.; Mercatali, L.; Ibrahim, T.; Campbell, N.; Schwarzenbach, H.; Pantel, K.; Amadori, D.; Kang, Y. Tumor-induced osteoclast miRNA changes as regulators and biomarkers of osteolytic bone metastasis. Cancer Cell 2013, 24, 542-556. [CrossRef]

219. Lee, D.Y.; Deng, Z.; Wang, C.-H.; Yang, B.B. MicroRNA-378 promotes cell survival, tumor growth, and angiogenesis by targeting SuFu and Fus-1 expression. Proc. Natl. Acad. Sci. USA 2007, 104, 20350-20355. [CrossRef]

220. O'Day, E.; Lal, A. MicroRNAs and their target gene networks in breast cancer. Breast Cancer Res. 2010, 12, 201. [CrossRef]

221. Gainford, M.C.; Dranitsaris, G.; Clemons, M. Recent developments in bisphosphonates for patients with metastatic breast cancer. BMJ 2005, 330, 769-773. [CrossRef] [PubMed]

222. Wong, M.; Pavlakis, N. Optimal management of bone metastases in breast cancer patients. Breast Cancer 2011, 3, 35-60. [CrossRef] [PubMed] 
223. Clines, G.A.; Guise, T.A. Molecular mechanisms and treatment of bone metastasis. Expert Rev. Mol. Med. 2008, 10, e7. [CrossRef]

224. Barre, P.V.; Padmaja, G.; Rana, S. Tiamongla Stress and Quality of Life in Cancer Patients: Medical and Psychological Intervention. Indian J. Psychol. Med. 2018, 40, 232-238. [CrossRef]

225. Weber, D.; O'Brien, K. Cancer and Cancer-Related Fatigue and the Interrelationships with Depression, Stress, and Inflammation. J. Evid. Based Complement. Altern. Med. 2017, 22, 502-512. [CrossRef]

226. Porcerelli, J.H.; Bornstein, R.F.; Porcerelli, D.; Arterbery, V.E. The complex role of personality in cancer treatment: Impact of dependency-detachment on health status, distress, and physician-patient relationship. J. Nerv. Ment. Dis. 2015, 203, 264-268. [CrossRef]

227. Thornton, L.M.; Andersen, B.L.; Carson, W.E. Immune, endocrine, and behavioral precursors to breast cancer recurrence: A case-control analysis. Cancer Immunol. Immunother. 2008, 57, 1471-1481. [CrossRef] [PubMed]

228. Baqutayan, S.M.S. The effect of anxiety on breast cancer patients. Indian J. Psychol. Med. 2012, 34, 119-123. [CrossRef]

229. Park, C.S.; Lee, H.-Y. Clinical utility of sympathetic blockade in cardiovascular disease management. Expert Rev. Cardiovasc. Ther. 2017, 15, 277-288. [CrossRef]

230. Fryzek, J.P.; Poulsen, A.H.; Lipworth, L.; Pedersen, L.; Nørgaard, M.; McLaughlin, J.K.; Friis, S. A cohort study of antihypertensive medication use and breast cancer among Danish women. Breast Cancer Res. Treat. 2006, 97, 231-236. [CrossRef]

231. Li, C.I.; Malone, K.E.; Weiss, N.S.; Boudreau, D.M.; Cushing-Haugen, K.L.; Daling, J.R. Relation between use of antihypertensive medications and risk of breast carcinoma among women ages 65-79 years. Cancer 2003, 98, 1504-1513. [CrossRef] [PubMed]

232. Le, C.P.; Nowell, C.J.; Kim-Fuchs, C.; Botteri, E.; Hiller, J.G.; Ismail, H.; Pimentel, M.A.; Chai, M.G.; Karnezis, T.; Rotmensz, N.; et al. Chronic stress in mice remodels lymph vasculature to promote tumour cell dissemination. Nat. Commun. 2016, 7, 10634. [CrossRef]

233. Spera, G.; Fresco, R.; Fung, H.; Dyck, J.R.B.; Pituskin, E.; Paterson, I.; Mackey, J.R. Beta blockers and improved progression-free survival in patients with advanced HER2 negative breast cancer: A retrospective analysis of the ROSE/TRIO-012 study. Ann. Oncol. Off. J. Eur. Soc. Med. Oncol. 2017, 28, 1836-1841. [CrossRef]

234. Montoya, A.; Amaya, C.N.; Belmont, A.; Diab, N.; Trevino, R.; Villanueva, G.; Rains, S.; Sanchez, L.A.; Badri, N.; Otoukesh, S.; et al. Use of non-selective $\beta$-blockers is associated with decreased tumor proliferative indices in early stage breast cancer. Oncotarget 2017, 8, 6446-6460. [CrossRef] [PubMed]

235. Pasquier, E.; Ciccolini, J.; Carre, M.; Giacometti, S.; Fanciullino, R.; Pouchy, C.; Montero, M.-P.; Serdjebi, C.; Kavallaris, M.; Andre, N. Propranolol potentiates the anti-angiogenic effects and anti-tumor efficacy of chemotherapy agents: Implication in breast cancer treatment. Oncotarget 2011, 2. [CrossRef]

236. Khosla, S.; Hofbauer, L.C. Osteoporosis treatment: Recent developments and ongoing challenges. Lancet Diabetes Endocrinol. 2017, 5, 898-907. [CrossRef]

237. Munzone, E.; Botteri, E.; Rotmensz, N.; Cipolla, C.M.; Zanelotti, A.; Adamoli, L.; Viale, G.; Goldhirsch, A.; Gandini, S. Prognostic effect of beta blockers (BB) in triple-negative breast cancer (TNBC) patients. J. Clin. Oncol. 2013, 31, 1061. [CrossRef]

238. Modi, N.D.; Tan, J.Q.E.; Rowland, A.; Koczwara, B.; Kichenadasse, G.; McKinnon, R.A.; Wiese, M.D.; Sorich, M.J.; Hopkins, A.M. The Influence of Pre-Existing Beta-Blockers Use on Survival Outcomes in HER2 Positive Advanced Breast Cancer: Pooled Analysis of Clinical Trial Data. Front. Oncol. 2020, 10, 1130. [CrossRef] [PubMed] 